\title{
Harnessing Social Capital for Resilience to Livelihood Shocks: Ethnographic Evidence of Indigenous Mutual Support Practices among Rural Households in Eastern Ethiopia
}

\author{
Getachew Shambel Endris, ${ }^{1}$ Paul Kibwika, ${ }^{1}$ Jemal Yousuf Hassan, ${ }^{2}$ and Bernard B. Obaa ${ }^{1}$ \\ ${ }^{1}$ Department of Extension and Innovation Studies, Makerere University, Kampala, Uganda \\ ${ }^{2}$ Department of Rural Development and Agricultural Extension, Haramaya University, Diredawa, Ethiopia \\ Correspondence should be addressed to Getachew Shambel Endris; getchs2006@gmail.com
}

Received 12 March 2017; Accepted 6 July 2017; Published 30 October 2017

Academic Editor: Sally Guttmacher

Copyright (c) 2017 Getachew Shambel Endris et al. This is an open access article distributed under the Creative Commons Attribution License, which permits unrestricted use, distribution, and reproduction in any medium, provided the original work is properly cited.

\begin{abstract}
In the absence of adequate support from formal social safety nets, rural households in Ethiopia have developed collective risksharing strategies to buffer them against adverse livelihood shocks, thus building their resilience capacities. Social capital and network based indigenous mutual support arrangements are the most important strategies that are institutionalized and widely practiced among rural households for centuries in Ethiopia to support households to cope with shocks. Nonetheless, resilience research and rural poverty alleviation policies have yet to fully recognize and embrace social capital as a tool to tackle poverty and vulnerability. Robust policy and academic studies on the role of indigenous welfare system with implications for social development policy making in Ethiopia are lacking. Using ethnographic techniques and simple descriptive statistics, we studied indigenous mutual support systems and how they shape the resilience trajectories of rural households against livelihood shocks within two selected PAs of Babille district of Oromia region. We found that mutual support practices are very effective in building coping resilience of households by smoothing consumption shocks. However, the traditional coping mechanisms often fail when the shock is systemic or covariate, when shocks last longer, and when a household has low level of human or finical capital.
\end{abstract}

\section{Introduction}

About two-thirds of the developing World's 3 billion rural people live in about 475 million small farm households, working on land plots smaller than 2 hectares [1]. Majority of these people are poor. They experience problems with food security. They have limited access to markets and other social services including insurance and safety net to support their livelihoods. This phenomenon exacerbates rural poverty, especially in Sub-Saharan Africa (SSA). The World Bank estimates over 380 million people in SSA living at or below the international poverty line of $\$ 1.90$ per person per day [2]. Among these, more than 220 million people are classified as chronically hungry [1]. Further, the incidence of poverty in these populations is more prevalent and deep-rooted among rural populations than urban residents [2]. Their ability to break and escape from the vicious circle of poverty is often jeopardized by vulnerability to frequent shocks. These shocks include adverse events that trigger a decline in household welfare, such as disease and pest, erratic climate, input price fluctuation, conflict, and policy shocks [3].

Ethiopia is one of the countries in SSA that have in the recent past experienced shocks with severe effects on the welfare of some rural communities. Shocks and vulnerability are the principal causes perpetuating poverty in the country [4]. About $80 \%$ of the population depends on farming and $43 \%$ of its GDP [5] and most of them do so in marginal areas which are vulnerable to prolonged draughts that have been escalated by the climate change phenomenon. The agricultural sector is characterized by risk-prone, rain fed, and low input and output production system (IPCC, 2005). Frequent droughts and floods occurring in the country have deteriorated the livelihood of farmers and their ability to recover from such shocks [6]. Smallholder farming households who nearly 
represent $80 \%$ in the Ethiopian economy [7] and largely depend on nature for their livelihood and are without any form of insurance services or formal safety nets, either by the state or the market, are the most vulnerable in this process. To surmount such shocks, there is need to build resilience through collective undertaking with underlying strong social bonds and networks between families and communities.

In the absence of or limited access to formal safety nets provided by the state or market, over time, rural communities in Ethiopia have developed a system of mutual support founded on social capital for guarding and buffering against shocks $[3,8]$. Indigenous mutual support practices (IMSPs) based on cooperation and social support networks that respond to social need and promote household and community wellbeing to shocks have been institutionalized and widely practiced among rural households in Ethiopia for many centuries [8-11]. These arrangements offer different services, such as mutual insurance, labor sharing, saving, and credit to rural households $[10,12]$ and fulfill many other sociocultural obligations. They are based on widely agreed norms of trust, moral obligation and reciprocities [10]. In addition, traditional values and religious beliefs underpin these practices, placing a strong cultural obligation and sanctions on community members to promote cooperation and collective action, build solidarity, and support vulnerable households to cope with shocks. Several studies [12-16] acknowledge the promotive and protective functions of informal mutual support arrangements: before or ex ante, during, and after crisis or ex post situations or shocks. Communities forming such arrangements tend to exhibit better recovery from shocks [16] and need public emergency assistance less urgently than those communities without such arrangements [17]. Nonetheless, studies on resilience, disaster management policy, and practices have yet to fully embrace indigenous mutual support arrangements as a vital component in addressing vulnerability [18-22] against livelihood shocks. This research is inspired by the recognition of indigenous mutual support systems in building resilience capacities of rural households against livelihood shocks in Ethiopia and particularly in Babille district of Eastern Hararghe Zone.

Indigenous mutual support practices are widespread among the case study community. However, the contribution of a social capital system for household and community resilience is rarely studied and documented. Development research and rural development policies that are geared towards enhancing the resilience of the rural poor in the country have focused on investments in formal interventions. Very little emphasis is placed on understanding, harnessing, and strengthening informal institutions for household resilience. Yet failure to recognize these capacities may lead to wastage of these resources, contribute to their gradual degradation, and eventually constrain households' future ability to cope with shocks by employing such networks.

It is now increasingly recognized that sustainable resilience system requires building diverse arrangements with a built-in overlap composed of formal and informal safety nets to offer alternative resources to the poor to draw upon when they need it the most [3, 20, 23, 24]. Identifying and harnessing locally available network based community mutual support arrangements are considered an important step. And this entails identifying and characterizing the different forms of locally available risk-sharing and risk-pooling arrangements and their role for household resilience. Apparently there are no clear policies and concrete information on the role of indigenous welfare system for enhancing the resilience of the poor households with implications to social development policy making. There is scanty information for policy makers and development practitioners on how informal arrangements shape the distribution, access, and use of resources at individual, household, and community level for an improved resilience against shocks. By examining the role of local forms of social capital for resilience, the current research aims to fill in this gap.

This paper therefore aims to explain how social capital shapes the distribution of, access to, and use of resources at individual, household, and community level for an improved resilience against shocks drawing on the experiences of households in $n$ Babille district of Eastern Ethiopia. The case study represents a diversity of indigenous mutual support practices that are applied to respond to adverse livelihood shocks and risks. The fundamental questions underlying this research include the following: (i) what are the different types of livelihood shocks that households in the case study community face? (ii) What are the different typologies of indigenous mutual support practices that households use to mitigate the pernicious effects of shocks and how are they characterized? And (iii) how do the different types of mutual support networks and groups shape the resilience trajectories of individual and households against vulnerabilities to livelihood shocks?

\section{Theoretical/Conceptual Framework}

As we seek to deepen our understanding and generate important knowledge on the role of social capital in household resilience against shocks, it is very important to draw on theoretical and empirical lessons on shocks, coping strategies, resilience, and social capital. By doing so, we shall construct the framework for this study.

2.1. Social Capital Theory. The works of Hoddinott and Quisumbing [25] provide some insights into how understanding shocks and their consequence facilitates the design of interventions to tackle their pernicious effects. They argue that assessing vulnerability essentially requires answering four interlinked questions: (i) Who is vulnerable? (ii) What are they vulnerable from (identification of shocks)? (iii) How do households manage risks and vulnerability (personal, state sponsored, and community based risk coping mechanisms)? And (iv) what is the gap between risks and risk management mechanisms (determinants of use and effectiveness of risk management practices)? These questions guide this research.

Shocks are adverse events that lead to the loss of household income and depletion or loss of productive assets hence perpetuating poverty and vulnerability in most developing countries [3]. These shocks can be idiosyncratic (those peculiar to a household, such as illness, injury, or unemployment) and covariate or systemic (those affecting the wider 
community at the same time or same place, such as natural disasters and crop loss caused by famine or epidemics). This study focuses more on the idiosyncratic or household level shock.

People always face shocks, both natural and man-made, and often devise their own responses and collective and institutional strategies to cope with and recover from them [26]. Alderman and Paxson (1992) classified the risk coping strategies employed by individual and households as those that smooth consumption intertemporally, through saving behavior, and those that smooth consumption across households, through risk-sharing practices. While intertemporal smoothing strategies enable a household to spread the effects of income shocks on consumption forward through time, by contrast risk-sharing helps to spread the effects of income and consumption shocks across households at any given point in time. A wide variety of mechanisms may be used for both intertemporal consumption smoothing and risk-sharing. Intertemporal smoothing may be accomplished through borrowing and lending in formal or informal markets, accumulating and selling assets, and storing goods for future consumption. Risk-sharing arrangements may be accomplished through formal institutions (such as insurance and selling crops before harvest for forward contracts for harvest) and informal mechanisms (including state-contingent transfers and remittances between friends and neighbors). In the absence of formal insurance or market based arrangements, households in developing countries mostly employ informal group based arrangements [3]. This arrangement predominantly involves a system of mutual assistance between family and kin networks and communities members to support each other in situations of a shock. These mechanisms are common in extended families, ethnic groups, neighborhood groups, and professional networks [27].

Central to these coping capacities is the role of social capital or network based informal arrangements. Social capital includes shared norms, rules, inherited habits, ethical values, and networks that facilitate mutually beneficial collective actions [28-32]. More precisely, social capital can be defined as a feature of society and social organization, such as trust, norms of reciprocity, and networks of civic engagement that can improve the efficiency of society to pursue shared objectives [32]. It involves institutionalized relationships of mutual acquaintances or membership in a group, which provides each of its members with the backing of the collectivityowned capital [30] to pursue a mutually beneficial collective action. Social capital may take different forms. Of particular interest in this research are both local level indigenous mutual support groups and networks that are practiced in groups, between networks of kin and neighbors, among tribe members in which mutual support behavior and reciprocities are regulated and reinforced by certain culturally defined norms and rules and moral obligations.

Drawing on a typology developed by $[33,34]$ for the study of indigenous mutual support system in Sub-Saharan Africa, indigenous mutual support practices can be further subdivided into four general categories. The first typology is family and kin based networks. This is based on family and kin obligations driven by moral obligations to support nurture and assist family and kin members against shocks. This predominantly utilizes bonding social capital between neighbors, kin, tribe, and friends. The second typology is community based networks that are utilized for a variety of social and economic purposes. These networks can be mainly utilized to access support from neighbors and the local elders, religious leaders in times of need. They are also utilized for cooperative community activities and labor support purposes, like crop storage and harvesting, house construction, and other activities that cannot be undertaken by individual domestic group alone. In addition, through such connections local people can also provide labor support for community infrastructure building. Such groups have the additional function of promoting community bonding, solidarity, and social cohesion. This predominantly utilizes bonding connection and bridging connections to a lesser degree. A third typology consists of mutual aid associations that are comprised of group of people who pool resources to meet contingencies as they arise or otherwise to promote saving and resource accumulation. This may utilize both bonding and bridging connections. The fourth type is comprised of religiously mandated obligations with the primary object of assisting the poor and the needy. In this paper we have applied these typologies in order to characterize the different forms of mutual support practices available in the case study community.

2.2. Social Resilience. The notion of "human capacity" to anticipate, resist, cope with, adapt to, or recover from the impact of shocks is at the epicenter of the conceptualization of resilience. Resilience thinking originates from socioecological systems where it is seen as a bridging concept to bring together environmental and social perspectives together to address environmental shocks and risks [35]. The ultimate purpose of resilience thinking is to help explain how human society deals with changes and risks in an interlinked social and ecological system and build adaptive capacities to cope with changes [36]. There is a growing interest by scholars, development practitioners, and policy makers seeking to apply resilience theory in understanding people's vulnerability to shocks and mechanisms to address them. Resilience theory has become one of the conceptual frameworks [3641] in understanding households vulnerability to adverse livelihood shocks and risks. In the process, several competing definitions of resilience have emerged.

In social studies, resilience refers to an ability, capability, or capacity of individuals, social groups, and even socialecological systems to live with disturbances, adversities, or disasters and "the ability to persist and the ability to adapt" $[18,39,40]$. In the ecological strand, resilience is considered as a key to adaptive capacity which has to do with learning, not only at an individual level but also on the level of organizations and networks that store knowledge and experience, create flexibility in problem solving, and balance power among interest groups. The notions of broad based collective action and social cohesion are duly noted as important pillars of resilience (if not sufficient) to effectively deal with uncertainties [42, 43], thus helping individual household build the required capacities against potential 
threats $[44,45]$. Thus, resilience describes the collective ability of a neighborhood or geographically defined area to deal with adverse shocks or stressors and efficiently resume the rhythms of daily life through cooperation and collective actions [18]. By combining all these, social resilience can thus be defined as the capacity of actors to utilize collectively owned capital in order to not only cope with and adjust to adverse conditions but also search for and create options and thus develop increased competence (i.e., positive outcomes) in dealing with a threat or shock. More specifically, in this paper, we define social resilience as the capacity of an individual, household, or community to access different types of capitals to respond to different livelihood shocks and to proactively reduce the risk of future shocks and the ability to persist, the ability to adapt and transform their livelihood situation. In this study, this definition will allow us to examine how individuals and households mobilize social capital resources to cope with and adapt to the effects of shocks in the case study community.

To effectively cope with and adapt to different livelihood shocks, resilience requires a diverse set of capacities. Drawing on the works of $[18,45]$ and the definition given above there are three central capacities for resilience. In this research, the role of social capital in household resilience against shocks will be examined against its potential to create or enhance these three components of a resilience system.

(i) Persistence or coping capacity (rehabilitating and stability) refers to the ability of an individual, household, or resilient system to cope with shocks, ex post, and to restore wellbeing to current levels after the events. It is the first response of households after crisis, mainly involving blocking the stressors. The primary aim of coping strategies is to maintain the health and nutritional status and improve the labor condition of households, ultimately, retaining household's asset level.

(ii) Adaptive resilience (incremental adjustment and flexibility) entails ex ante (before shock) long-term preventive strategy/actions. Adaptive measures are aiming towards building household and community asset so as to mitigate the impact of predicted shock. Adaptive resilience is mainly about creating new assets and capabilities through incremental adjustments in the livelihood and this involves activities that will lead to a sustainable increase in household and community asset level. At local community level, colearning between individual and households, collaboration for collective actions, and networking for resource sharing are considered vital elements in building adaptive capacities.

(iii) Transformative capacity (transformational response and change) is the highest level of adaptation process. Building transformative capacity is the most challenging at local community level. This is because this capacity requires households and communities to have access to political resources and forging linkages and alliances with external agencies, mainly with formal institutions, such as banking and insurance, credit and saving associations, and cooperatives. In this research, transformative capacity is applied to see household's linkages with and access to external resources.

\subsection{Illustrating the Relationship between Social Capital and} Social Resilience. Social capital has been applied to understand the trajectory of individuals (based on which resources are accessed through social networks) as well as communities (based on levels of trust, collective action, and other public goods) in coping with shocks and risks. Empirical evidences from developing countries suggest that social networks and groups provide financial and nonfinancial resources (e.g., emotional, sheltering, and information) during disaster situations. In this paper, in order to assess the contribution of social capital in building the resilience capacities of households in the framework by Bernier and Meinzen-Dick [10], it is necessary to illustrate the relationship between social capital and social resilience (also see the classification [18, 46]). This relationship has also been portrayed by a schematic diagram (see Figure 1).

(i) Bonding social capital describes the connections between and among individuals who are emotionally close, such as friends and family. This kind of connection is characterized by homophily: high level of similarity in available information, demography, and economic and social status [47]. It indicates strong family ties where social relationships are based on strong trust and reciprocity. Thus most of the time this type of connection is closed and exclusive $[28,48,49]$, in the sense that access to membership and benefit of membership are restricted to those individuals and households who have similarity. Thus, this type of connection often entails exclusion of those households that are not similar [50,51]. The strong connection often makes this type of social capital good for providing immediate social assistance in times of shocks [52] mostly after the shocks have happened. This type of social capital is considered important in the creation of coping capacity. In the context of this research, this type of connections mostly includes family and kin mutual support networks, neighbors, and gender based mutual assistance groups. In this study we shall examine the role of this type of connections in building the coping capacities of individual and households against shocks and risks.

(ii) Bridging social capital connects people that span social groups, such as race, tribes, different social groups and villages for mutual support activities. It serves as a bridge linking between different bonding social capitals. It enables households belonging to other groups to access extra resources, such as novel information, knowledge, and financial resources that might not be accessed through bonding connections [53]. The information and knowledge traded between groups allows the community to benefit from a diversified social endowment accumulation and, therefore, more encourages more social capital [54]. Thus, this 


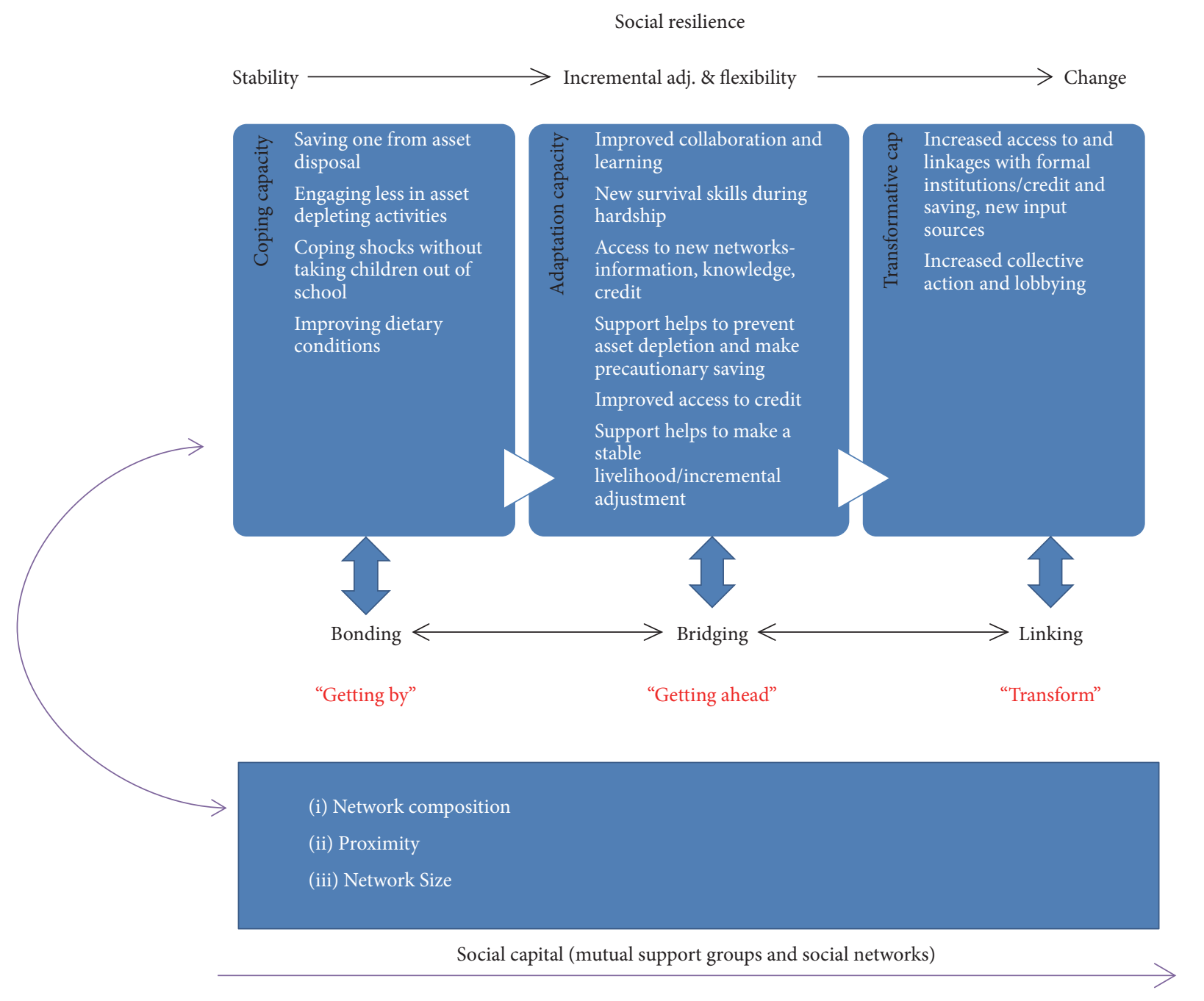

FIGURE 1: The research framework.

type of social capital is considered important in the creation of adaptive resilience capacities, involving incremental adjustment in income and livelihood situation for better adaptation. In this study this type of connection includes those groups and networks that link different segments of the society for cooperative community activities, such as mutual aid associations, burial societies, and labor reciprocity networks at community level. Accordingly, we shall illustrate how these types of connection shape the adaptive resilience capacities of households.

(iii) Linking social capital represents connections between individuals and groups in different position of financial and political power. It is considered as an essential mechanism for "forging alliances with sympathetic individuals in the position of power" [55] and for leveraging resources from formal and informal institutions beyond the local community [46]. Scholars consider linking social capital very vital in the creation of transformative resilience capacity. In this study, we shall examine the role of informal groups and networks in linking local people to external resources.

Each type of ties has importance for household resilience. It is however very important to note that it is always the balanced combination of these three that makes a difference in the lives of the poor to improve their resilience capacities. Just as the body needs different combinations of vitamins, a healthy and effective and resilient community needs the blends of the different types of social capital [56].

\section{Research Methodology}

3.1. Research Design and Sampling. Understanding how society shapes the resilience of individual and households and vice versa and how individuals and households mobilize and 


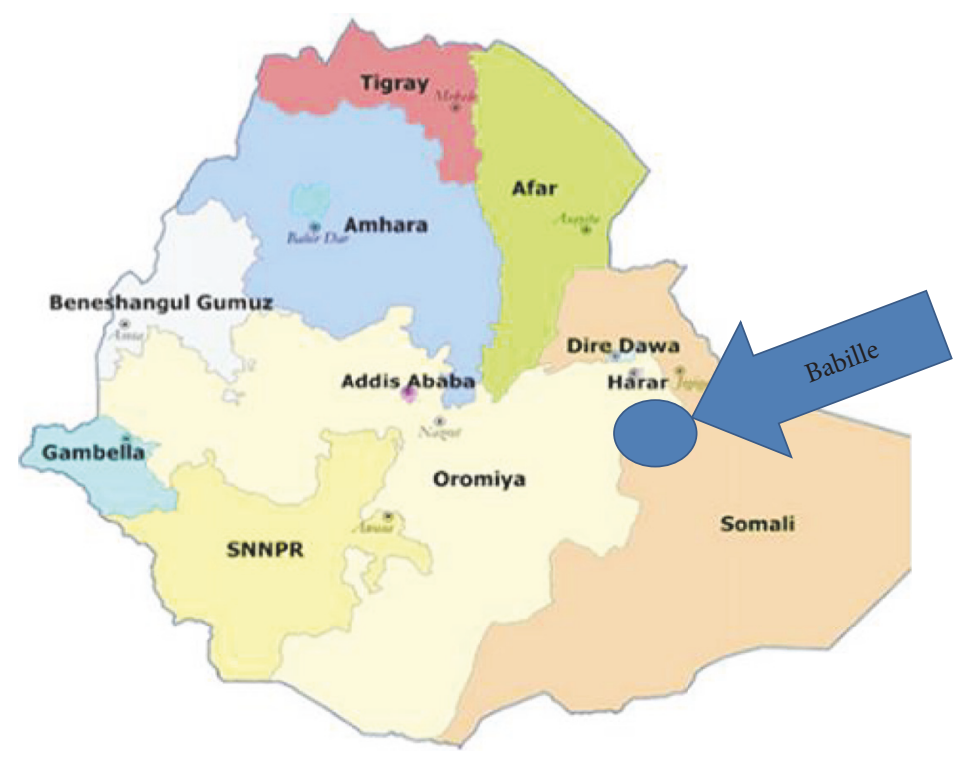

Figure 2: Maps of Ethiopia and Babille.

utilize indigenous mutual support resources to collectively and individually cope with and adapt to the effects of shocks is an iterative and interactive process that is context specific. Hence, reflexive ethnographic case study approach [57] was adopted. This allows representation of competing versions of reality and captures multiple perspectives of people's actions and accounts on everyday experiences. The study relied on qualitative data engrained in people's accounts of their lived experiences in their day to day livelihood activities and network relationships to cope with and adapt to livelihood situations, thus extracting "meanings" from insiders' standpoint: the feelings, perceptions, ideas, beliefs, and interpretative processes of members of society as they themselves understand and articulate them [58]. To complement the qualitative data, household survey data were also generated to explain household vulnerability to different livelihood shocks and household network characteristics.

Ethiopia is a federal country divided into 11 regions. Each region is further subdivided into administrative units (zones) and the zones are divided into districts or Woredas. A Woreda comprises peasant associations (PAs) known as kebeles, which are the smallest administrative units consisting of a few villages. This study was conducted in Eastern Hararghe Zone of Oromia regional state, which is also one of the largest, riskprone, and most populous zones of Oromia regional states. This study is conducted in two kebeles (kebele (plural kebeles) is the smallest administrative unit in Ethiopia; it is often used interchangeably with the English term "peasant association"; approximately, a single kebele comprises 500 households) of Babille District, Berkelle and Sheik Husain kebeles (See Figure 2 for map of Ethiopia and study locations). Babille district was selected based of its high vulnerability to shocks and history of utilization of mutual support practices in Eastern Hararghe Zone. The two selected kebeles represented the two main agroclimatic zones: arid and semiarid. Subsistence agriculture is the major livelihood activity for the majority of households in the study area, with agropastoralism being the most dominant farming system. The crops grown include ground nut, sorghum, and potato and camels and goats being the most common livestock.

A three-stage sampling procedure was used to select the kebeles. To select the kebeles, the 25 kebeles in Babille district were first characterized based on their size, diversity of mutual support groups, diversity of tribes, and access to main road. This has been done in consultation with development agents working in the area. Out of 25 kebeles two were selected purposively: Berkelle and Sheik Hussain based on their proximity to each other and access to transportation.

In Ethiopia, administrative/governance and development activities are organized based on village and kebele boundaries. The village represents a community. Two villages from each kebele were selected for the study based on tribal diversity proximity for ease of movement between the two villages. Tribal diversity is important in understanding how social capital and resilience are built within and across tribes within a community. The third stage of the sampling respondents involved identifying respondents for the survey and ethnographic interview. For the ethnographic field work, households were sampled based on neighborhood proximity, access to different social capital resources, and settlement history in the location, marital status, and gender. Accordingly, a total of 25 households were drawn. For the quantitative survey, a total of 60 households were drawn purposively from each sampled village. This has been done in consultation with kebele development agents as the list of households based on these variables already documented and made available for other formal project activities. $70 \%$ of the respondents are women.

3.2. Instrumentation and Data Collection. The data for this study is obtained using individual, household, and community interview and participant and nonparticipant observations from 2014 to 2017. 
Qualitative data were collected through individual qualitative interviews using interview checklist and participant observation. In addition to groups and community interviews, key informant interviews were also employed. The interview checklist included information/questions pertaining to households' social networks and groups for accessing support during shocks (ex post and ex ante crisis situations), labor support, credit, charitable gifts, sentimental and moral support, and so on. Most of the information is kept in the form of recoded life experiences of individual and households. Observation data (participant and nonparticipant observation) was collected using observation checklist. The checklist included information on day to day livelihood activities of households. Observation data is basically generated to examine the season specific shocks and the seasonal variability in performance of mutual support groups across seasons. This is particularly to determine how community risk-sharing practices and social networks/reciprocity networks function across different seasons including dry season and harvesting season and the social strategies households employ to cope with changes. The quantitative data from the survey were gathered using semistructured interviews of sampled households. The quantitative data from the household survey was mainly collected from semistructure interviews of sampled households. Questions in the survey instrument focused on identifying, characterizing, and ranking of frequently occurring shocks, access to livelihood resources, coping strategies, and social network characteristics that individual and households use to acquire resources to cope with shocks.

In order to identify priority shocks, survey respondents were asked to mention 5 major shocks that they have had experienced over the last 5 years. They were also asked to prioritize them based on importance. The household interview has been preceded by a community discussion that deals with the pairwise ranking of major communitywide shocks that frequently took place over the past 10 years. In order to manage discussions and generate in-depth information, the community discussion has been divided into various small groups.

Household network characteristics or network information was collected on persons from whom the household received labor support, rented land, accessed credit, shared market, and crop production information and received immediate support during crisis situation. Households in the quantitative survey were asked to provide detailed information about the five most important people you can rely on in time of need for support, both within the village and elsewhere. In addition, they were asked whether there were other people, beyond these five, who could be relied on for help in time of need. We call such individuals a "network" [59]. And in this section we provide descriptive statistics on two major dimensions of these networks: network proximity and characteristics of individuals within a household network.

In addition, sociodemographic characteristics of the person from whom households get support including age, gender, tribal affiliation, and location have been asked. Tribal affiliation and gender are included as important variables as they may be related to differences in composition and diversity of social networks and access to resources among households. Similarly location provides important information in order to be able to determine the type of social capital households possess (such as bonding, bridging, and linking social capital). It also provides information on whether households differ in quantitative and qualitative terms regarding support originating within and outside the villages [60].

In addition to social networks, households were also asked to identify the list of indigenous mutual support groups which they are a member of/get support from and identify the kind of services/resources they acquire. Membership characteristics, modalities of support, condition for membership, norms and rules governing membership and reciprocities/reinforcement mechanisms, type of insurance (partial and complete), membership contributions, and membership composition were among the variables used to characterize mutual support groups. The same information has been utilized in order to categorize and characterize mutual support groups in different typologies (drawing on [33] and [34]). Household interview on mutual support groups was preceded by a KII with the local elders, leaders of mutual support groups. This is to gain an in-depth insight into the history and trajectories of indigenous mutual welfare practices and the type of mutual support practices available in the area. A total of $15 \mathrm{KII}$ in different villages have been conducted.

Household wealth ranking exercise has been conducted in order to be able to gain an overall insight into the household or community asset level. This was later employed to analyze the relationship between household asset level and access to and ability to mobilize different livelihood resources or support from networks and groups (whether or not one's access to resources from networks and groups is determined by possession of different livelihood resources/capitals or position in the wealth ladder). Accordingly, three major wealth categories were developed based on community discussions and household and individual interviews conducted in different villages. Participants operationalized household asset level based on possession of key household and community assets/capitals (natural, physical, political, social, human, and financial capitals).

\subsection{Analysis Variables. See Table 1.}

3.4. Methods of Data Analysis. Qualitative data obtained from in-depth ethnographic interviews and KII were analyzed using content analysis (mainly discourse analysis). In general, qualitative data was analyzed phrase by phrase and organized into themes [61]. The major themes which emerged in the categorization included shocks, groups and networks, indigenous mutual support groups, and social resilience. Based on these topics, sections with similar themes were merged accordingly. Finally, results are organized into five major sections: shocks in the case study community, networks, groups and collective action for resilience, typologies of indigenous mutual welfare practices, and roles of mutual support practices in mitigating shocks and building resilience. The implication of indigenous mutual support 
TABLE 1: Analysis variable.

\begin{tabular}{|c|c|}
\hline Variable & Measurement \\
\hline Household demographics & $\begin{array}{c}\text { Sex } \\
\text { Household size } \\
\text { Ethnic/tribal affiliation }\end{array}$ \\
\hline Social networks & $\begin{array}{c}\text { Network composition/diversity } \\
\text { Membership in groups } \\
\text { Network proximity/ } \\
\text { Network size/density } \\
\text { Type }\end{array}$ \\
\hline Access to household assets & $\begin{array}{l}\text { Human capital (household labor condition, number of children, level of education, } \\
\text { family wellbeing) Financial capital (money saved in the bank, money kept in the } \\
\text { form of livestock), physical capital (land), political capital }\end{array}$ \\
\hline \multirow{4}{*}{ Level of participation in groups } & Number of groups a household belongs to \\
\hline & Types and diversity of groups \\
\hline & Frequency of participation and reciprocities \\
\hline & Responsibility \\
\hline Access to resources & Information, labor, financial, sentimental \\
\hline Social resilience (dependent variable) & Coping, adaptive, and transformative capacities (see Figure 1 on the types of data) \\
\hline
\end{tabular}

practices for resilience was analyzed mainly using the analysis variables as suggested in the theoretical frame work (Figure 1) and different analysis variables (Table 1). On the other hand, quantitative data collected on different aspects of social networks and groups (network characteristics such as proximity, composition) and household shocks has been analyzed using simple descriptive statistics (percentage and frequency).

Interviews were recorded and also captured in notebooks. Every day, immediately after a session of interview and group discussions, data were transcribed in Afaan Oromo and later translated in English. Relevant sections were clustered in the respective themes. Transcripts in Afaan Oromo were used for validation of the information with respondents. The "emic-etic technique" [62] was used to extract meaning for interpretation of expressions. Discourse analysis [63] was used to break down meanings based on the local use of language.

\section{Result and Discussions}

This section presents the major findings and discussions of the study. The first few sections provide detailed account of the general environment our respondents' live, including the identification of major community and household level shocks. In the latter stages of this section, we have tried to characterize the different types of social capital practices available in the case study community and how these practices shape the resilience trajectories of households against shocks and risks.

4.1. Shocks in the Case Study Community. Table 2 shows the ranking of mostly frequently occurring shocks in the case study communities over the past 10 years.

Table 2 shows that the most commonly reported worst shocks based on frequency of occurrence (top 6) in the case study community over the past 10 years include conflict shocks, drought shocks, pest diseases that affected animal, pest diseases that affected crops, illness of head, spouse, or another person, and death of head or spouse. High input price fluctuation, wedding expenses, theft, shortage of forage, and policy related shocks have been ranked, respectively, from 7 to 11 . While these data provide us with detailed overview of the types of shocks experienced by community members over the past 10 years, they do not give us information on level of importance at household level. Table 3 summarizes the household self-report of priority shocks based on level of importance. This has been generated by asking households one common question: has this household been affected by a series of shocks, an event that led to a series of depletions or reduction in your asset holdings, caused your household income to fall substantially, or resulted in a significant reduction in consumption and household welfare in general? This was done by consulting the list of shocks established at the community level (Table 2). Households were simply asked to rank them based on their circumstances along with explanations.

Quantitative data from household ranking of shocks shows congruence for the top five severe shocks: conflict shocks, $76.7 \%$, drought and hunger, $73.3 \%$, pest diseases affecting livestock, $90 \%$, pest diseases affecting crops, $86.7 \%$, and illness of head and spouse, $36.7 \%$ (see Figure 3 ).

The conflict in Berkelle and Sheik Hussain is covariate shock. It is a common occurrence especially in areas that border on the Somalia. The conflicts arise from struggle for pasture and expansion of territory. These conflicts have existed for a long time in history and are considered the most severe shocks to livelihoods of the communities. According to key informants this conflict is one of the deadliest and most recurrent types of all the other shocks in the locality, in terms of the material, human, and social costs, and affects utilization of the resources including social capital. These shocks lead to 
TABLE 2: Community ranking of mostly frequently occurring shocks, field survey, 2015.

Most commonly reported shocks at community level (covariate shocks)

Conflict shock (territorial conflict/tribal conflict shock) (political/social shock)

Drought and hunger (climatic shocks)

Pest and disease that affected animals (cat

Pest and diseases that affected crops

Illness of household head, spouse, or another person (health shocks)

Death of household head, spouses, or another person (health shocks)

Difficulty in obtaining inputs or high input price fluctuation

Wedding expenses

Theft (crime shock)

Shortage of forage (climatic shock)

Policy shocks (land grab, mobility, and migration ban)
Ranking based on frequency of occurrence

3

5

6

7

8

9

10

11

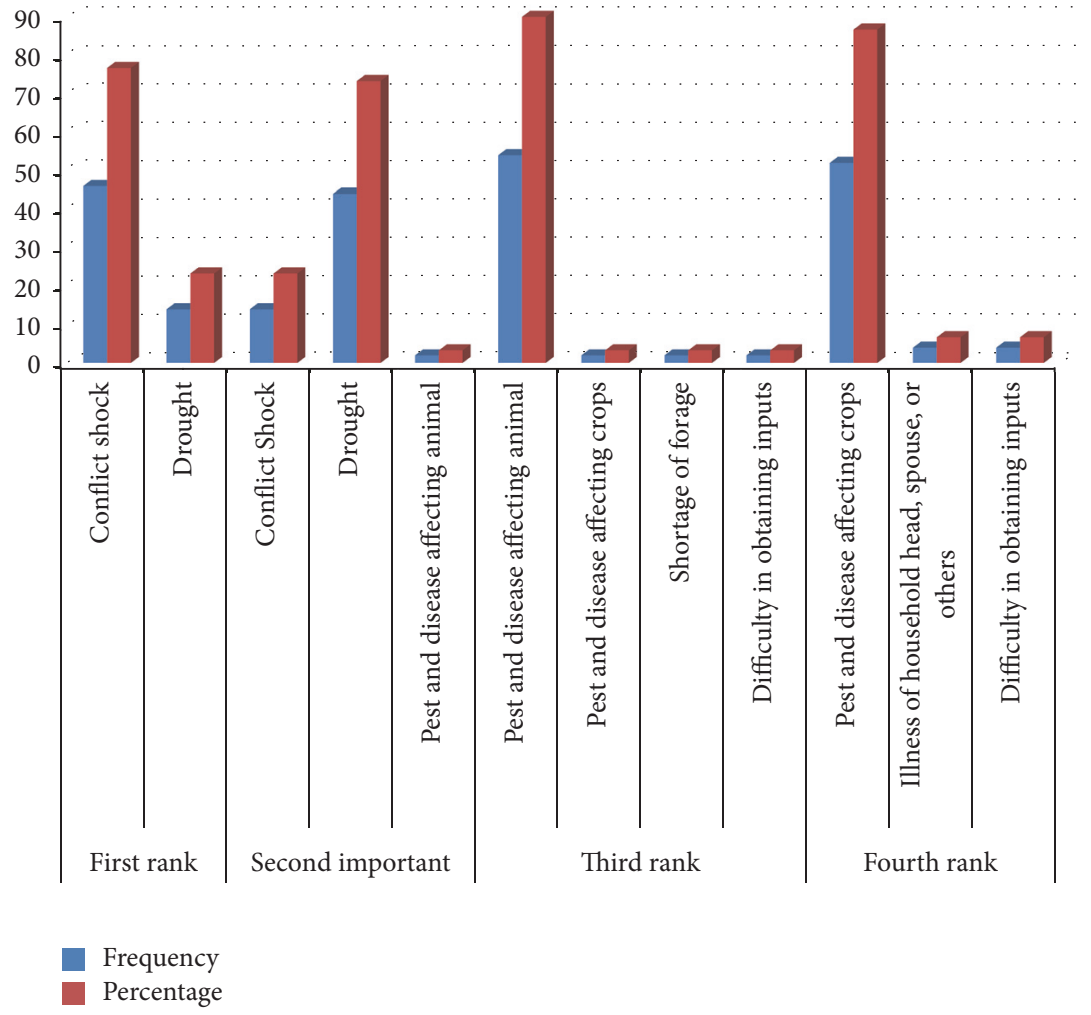

FIGURE 3: Household self-report of shocks based on importance.

involuntary migration of some tribes, forcing them to leave behind their assets and valuables including food and/or crops in the gardens. The migrations, for example, destroy the social set-up that supports the most vulnerable categories of people such as single mothers, the old, the landless, and the disabled. These largely depend on relatives, friends, and other people in the community for their existence. When this set-up is destabilized by migrations such people suffer most as they are left helpless and unable to live on their own. Their social support system for their livelihood is destroyed. Further, the conflict affects the human capital formation. This is in the sense of losing productive manpower and interruption of schools during times of conflict for most children. According to key informants the conflicting communities tend to target the most active members of the community especially the youth and men who take on the frontline tasks of protecting their families and tribes, thereby depleting not only the economically active people but also devastating the future of the communities and their ability to recover from such shocks. The emotional distress created during such conflicts creates a 
TABLE 3: Household self-report of priority shocks.

\begin{tabular}{|c|c|c|c|}
\hline $\begin{array}{l}\text { Rank category of } \\
\text { most important } \\
\text { shocks to the } \mathrm{HH}\end{array}$ & Shocks & Frequency & $\%$ \\
\hline \multirow{3}{*}{ 1st } & Conflict shock & 46 & 76.7 \\
\hline & Drought & 14 & 23.3 \\
\hline & Total & 60 & 100 \\
\hline \multirow{4}{*}{ 2nd } & Conflict shock & 14 & 23.3 \\
\hline & Drought & 44 & 73.3 \\
\hline & $\begin{array}{l}\text { Pest and disease affecting } \\
\text { animal }\end{array}$ & 2 & 3.3 \\
\hline & Total & 60 & 100.0 \\
\hline \multirow{5}{*}{$3 \mathrm{rd}$} & $\begin{array}{c}\text { Pest and disease affecting } \\
\text { animal }\end{array}$ & 54 & 90.0 \\
\hline & $\begin{array}{l}\text { Pest and disease affecting } \\
\text { crops }\end{array}$ & 2 & 3.3 \\
\hline & Shortage of forage & 2 & 3.3 \\
\hline & Difficulty in obtaining inputs & 2 & 3.3 \\
\hline & Total & 60 & 100.0 \\
\hline \multirow{4}{*}{4 th } & $\begin{array}{c}\text { Pest and disease affecting } \\
\text { crops }\end{array}$ & 52 & 86.7 \\
\hline & $\begin{array}{l}\text { Illness of household head, } \\
\text { spouse, or others }\end{array}$ & 4 & 6.7 \\
\hline & Difficulty in obtaining inputs & 4 & 6.7 \\
\hline & Total & 60 & 100.0 \\
\hline \multirow{9}{*}{5 th } & $\begin{array}{l}\text { Pest and disease affecting } \\
\text { crops }\end{array}$ & 2 & 3.3 \\
\hline & Lack of potable water & 4 & 6.7 \\
\hline & Policy shock & 14 & 23.3 \\
\hline & $\begin{array}{l}\text { Illness of household head, } \\
\text { spouse, or others }\end{array}$ & 22 & 36.7 \\
\hline & $\begin{array}{c}\text { Death of head, spouses, or } \\
\text { others }\end{array}$ & 4 & 6.7 \\
\hline & Difficulty in obtaining inputs & 10 & 16.7 \\
\hline & $\begin{array}{l}\text { Wedding and funeral } \\
\text { expenses }\end{array}$ & 4 & 6.7 \\
\hline & & 60 & 100.0 \\
\hline & Total & 60 & 100 \\
\hline \multirow{9}{*}{ 6th } & $\begin{array}{l}\text { Pest and disease affecting } \\
\text { animal }\end{array}$ & 2 & 3.3 \\
\hline & Shortage of forage & 2 & 3.3 \\
\hline & Lack of potable water & 14 & 23.3 \\
\hline & Policy shock & 16 & 26.7 \\
\hline & Theft & 2 & 3.3 \\
\hline & $\begin{array}{l}\text { Illness of household head, } \\
\text { spouse, or others }\end{array}$ & 6 & 10.0 \\
\hline & $\begin{array}{c}\text { Death of head, spouses, or } \\
\text { others }\end{array}$ & 14 & 23.3 \\
\hline & $\begin{array}{l}\text { Wedding and funeral } \\
\text { expenses }\end{array}$ & 4 & 6.7 \\
\hline & Total & 60 & 100.0 \\
\hline \multirow{6}{*}{7 th } & $\begin{array}{l}\text { Pest and disease affecting } \\
\text { animal }\end{array}$ & 2 & 3.3 \\
\hline & $\begin{array}{c}\text { Pest and disease affecting } \\
\text { crops }\end{array}$ & 2 & 3.3 \\
\hline & Shortage of forage & 18 & 30.0 \\
\hline & Lack of potable water & 4 & 6.7 \\
\hline & Policy shock & 4 & 6.7 \\
\hline & Theft & 6 & 10.0 \\
\hline
\end{tabular}

TABLE 3: Continued.

\begin{tabular}{|c|c|c|c|}
\hline $\begin{array}{l}\text { Rank category of } \\
\text { most important } \\
\text { shocks to the } \mathrm{HH}\end{array}$ & Shocks & Frequency & $\%$ \\
\hline & $\begin{array}{l}\text { Illness of household head, } \\
\text { spouse, or others }\end{array}$ & 2 & 3.3 \\
\hline & $\begin{array}{c}\text { Death of head, spouses, or } \\
\text { others }\end{array}$ & 14 & 23.3 \\
\hline & Difficulty in obtaining inputs & 8 & 13.3 \\
\hline & Total & 60 & 100.0 \\
\hline \multirow{11}{*}{8 th } & Drought & 2 & 3.3 \\
\hline & $\begin{array}{c}\text { Pest and disease affecting } \\
\text { crops }\end{array}$ & 2 & 3.3 \\
\hline & Shortage of forage & 10 & 16.7 \\
\hline & Lack of potable water & 6 & 10.0 \\
\hline & Policy shock & 4 & 6.7 \\
\hline & Theft & 2 & 3.3 \\
\hline & $\begin{array}{l}\text { Illness of household head, } \\
\text { spouse, or others }\end{array}$ & 22 & 36.7 \\
\hline & $\begin{array}{c}\text { Death of head, spouses, or } \\
\text { others }\end{array}$ & 2 & 3.3 \\
\hline & Difficulty in obtaining inputs & 6 & 10.0 \\
\hline & $\begin{array}{c}\text { Wedding and funeral } \\
\text { expenses }\end{array}$ & 4 & 6.7 \\
\hline & Total & 60 & 100.0 \\
\hline \multirow{8}{*}{ 9th } & Shortage of forage & 12 & 20.0 \\
\hline & Lack of potable water & 12 & 20.0 \\
\hline & Policy shock & 4 & 6.7 \\
\hline & Theft & 2 & 3.3 \\
\hline & $\begin{array}{c}\text { Death of head, spouses, or } \\
\text { others }\end{array}$ & 22 & 36.7 \\
\hline & Difficulty in obtaining inputs & 4 & 6.7 \\
\hline & $\begin{array}{l}\text { Wedding and funeral } \\
\text { expenses }\end{array}$ & 4 & 6.7 \\
\hline & Total & 60 & 100 \\
\hline \multirow{8}{*}{ 10th } & Shortage of forage & 4 & 6.7 \\
\hline & Lack of potable water & 16 & 26.7 \\
\hline & Policy shock & 6 & 10.0 \\
\hline & $\begin{array}{l}\text { Illness of household head, } \\
\text { spouse, or others }\end{array}$ & 2 & 3.3 \\
\hline & $\begin{array}{c}\text { Death of head, spouses, or } \\
\text { others }\end{array}$ & 4 & 6.7 \\
\hline & Difficulty in obtaining inputs & 16 & 26.7 \\
\hline & $\begin{array}{l}\text { Wedding and funeral } \\
\text { expenses }\end{array}$ & 12 & 20.0 \\
\hline & Total & 60 & 100.0 \\
\hline \multirow{7}{*}{ 11th } & Shortage of forage & 10 & 16.7 \\
\hline & Lack of potable water & 2 & 3.3 \\
\hline & Policy shock & 12 & 20.0 \\
\hline & Theft & 16 & 26.7 \\
\hline & Difficulty in obtaining inputs & 12 & 20.0 \\
\hline & $\begin{array}{l}\text { Wedding and funeral } \\
\text { expenses }\end{array}$ & 8 & 13.3 \\
\hline & Total & 60 & 100.0 \\
\hline \multirow{5}{*}{12 th } & Shortage of forage & 2 & 3.3 \\
\hline & Policy shock & 2 & 3.3 \\
\hline & Theft & 32 & 53.3 \\
\hline & $\begin{array}{l}\text { Wedding and funeral } \\
\text { expenses }\end{array}$ & 24 & 40.0 \\
\hline & Total & 60 & 100.0 \\
\hline
\end{tabular}


long-term spiral of revenge attacks which in turn perpetuates the conflict from generation to generation. This phenomenon depletes the most productive human capital mainly the youth and men thereby exacerbating the vulnerability of the community to shocks. Because of the reoccurrence of these conflicts, community self-defense becomes an important survival strategy. For this reason, at the time of this research most youngsters in these communities had either bought guns or were saving money to buy guns (though illegally) to protect their respective communities. In this respect, a local development agent narrated the following:

Last year alone (referring to the year 2015), our office estimated that a total of 45 "machine guns", each with an estimated cost of USD 2000 were purchased by farmers from this kebele alone from arm smugglers coming from Somalia. This is hard earned money that could have gone into improving the food security status of households but is diverted purchase of guns and bullets as this is priority for their survival. You can imagine how painful it is to those families to spend that much on weapons while they can hardly have two meals a day. Yet the government cadres and development agents like me, we talk about food security and food aid. If we can stop these conflicts, these communities are capable of rebuilding their physical assets and strengthen their social capital to sustain themselves without external aid. It is the responsibility of government to intervene and stop these deadly conflicts but no serious efforts have been demonstrated on part of government.

Drought and its effects of hunger are climatic or weather induced shocks which in turn trigger the social conflicts. As matter of fact, according to reports of the district's office of rural development, roughly more than $70 \%$ of household vulnerability affecting both animal and human wellbeing in the locality is caused by climate-induced shocks. In our data too, more than half of the 11 major household and community-wide shocks identified are rooted in erratic climate changes. Shocks related to pests and diseases for livestock and crops (ranked 3rd and 4th) can also be related to climatic conditions. It can therefore be argued that failure to mitigate the effects of drastic climatic conditions is the root cause of the vulnerability of these communities.

Policy shock is yet another very important problem (though ranked last) that is resulting in significant consumption and income losses. The major ones include land grabs and migration or mobility ban. In one of the group discussions, one of the participants says the following about how land grabbed by the local government authorities is affecting their livelihood:

The local government has recently issued 45 hectares of land to a local investor. In the beginning, the officials told us that this investment will promote food security status, enhances technology and skill transfer, and off farm employment opportunities of the local people. However, we found the local investor no better than ordinary farmers. They grow what we grow. Where is the technology and skill transfer? Skill and technology transfer exists only when the local investors practice better agricultural practices than we do. Besides, in terms of wage, they are paying far more less than (half the wage rate) what a farmer earns when he engages in a causal labor for better off famers. They are also flooding the local market because they produce what we produce in small scale. We do not understand anymore the essence of investment. According to me, this is nothing but land grabbing!!!!

The migration ban and mobility restriction on the agropastoral community are the other pressing problem currently affecting the adaptive and coping capacities of the agropastoral communities in Babille. Mobility of cattle and people is one of the most important age-old traditional coping strategies of the agropastoral communities. It allows a wide ranging movement for the agropastoral community from place to place for pasture and water to their animals. However, in recent years, this is made impossible due to the sedentarization policy of the government. A senior development worker in the area says the following in relation to how the sedentarization policy of the government and mobility restrictions is affecting the life style, identity, and coping strategies of households in the area:

One of the most important adaptation strategies for the agro-pastoral community in this locality and elsewhere in Babille used to be the mobility of people and cattle from one place to another for pasture and water. For more than a decade now, the government has officially banned the mobility of agro-pastoral communities from one place to another. This is due to the increasing sedentarization policy of the government. As a result, the identity, culture, and livelihood of agropastoral communities and their survival strategies are under threat. You cannot force this people to do farming and agriculture in a situation where there is no rain and land is scarce. The last 3 years there is a consecutive failure of harvest in rows. This means no animal feed, water and food. Several animals have died. Their families are starving. You cannot deny them mobility. It is their right. Bottom-line, it is the only way to survive.

These are some of the most important shocks (idiosyncratic and covariate) affecting the adaptive and coping trajectories of household in the case study communities.

\section{Household Assets Ownership and Access to Resources}

Table 4 shows household wealth categories analyzed based on possession of major livelihood capitals/assets. This helped us to examine whether access to any of these capitals determines or shapes household's access to social capital resources. 
TABLE 4: Household asset categories.

\begin{tabular}{|c|c|c|c|}
\hline & \multicolumn{3}{|c|}{ HH wealth category } \\
\hline Capitals & $\begin{array}{l}\text { Tujara (wealthy) } \\
\text { (12\% of HHs) }\end{array}$ & $\begin{array}{l}\text { Woya (middle class) } \\
\text { (estimated to be } 53 \% \mathrm{HHs} \text { ) }\end{array}$ & $\begin{array}{l}\text { Miskina (the poorest) } \\
\text { (estimated to be } 35 \% \mathrm{HHs} \text { ) }\end{array}$ \\
\hline Natural & $\begin{array}{l}\text { (i) } 2 \text { hectares of land (at least) } \\
\text { (ii) Up to } 10 \text { pairs of oxen } \\
\text { (iii) } \geq 20 \text { camels } \\
\text { (iv) Shoats } 10-15 \\
\text { (v) } 4-5 \text { donkeys } \\
\text { (vi) Sorghum } 2000 \mathrm{~kg} \\
\text { (vii) G-nut } 1500 \mathrm{~kg} \\
\text { (viii) Maize } 1500 \mathrm{Kg}\end{array}$ & $\begin{array}{l}\text { (i) Mostly } 1 \text { acre } \\
\text { (ii) Pair of oxen } \\
\text { (iii) Shoats } 3-4 \\
\text { (iv) Sorghum } 500 \mathrm{~kg} \\
\text { (v) G-nut } 300 \mathrm{~kg} \\
\text { (vi) Maize } 100 \mathrm{~kg} \\
\text { (vii) Camel } 1-2\end{array}$ & $\begin{array}{l}\text { (i) Ranges from half } 1 \text { acre up to landless } \\
\text { (ii) Own marginal land } \\
\text { (iii) Most do not own draft animal } \\
\text { (iv) Very few have modest sized land but } \\
\text { they rent it out }\end{array}$ \\
\hline Physical & $\begin{array}{l}\text { (i) Cemented house (bricks), iron } \\
\text { roofing, multiple rooms }\end{array}$ & $\begin{array}{l}\text { (i) Mostly iron roof, mud wall, ordinary } \\
\text { fencing }\end{array}$ & $\begin{array}{l}\text { (i) House: mostly thatched grass } \\
\text { (ii) Their fence: a natural bush }\end{array}$ \\
\hline Political & $\begin{array}{l}\text { (i) Mostly have linkages with local } \\
\text { politicians and tribal leaders } \\
\text { (ii) They influence decisions } \\
\text { (iii) People listen to them voice no } \\
\text { matter how } \\
\text { (iv) However, they rarely listen to others }\end{array}$ & $\begin{array}{l}\text { (i) Generally have good relations with } \\
\text { community members and politician but } \\
\text { cannot influence decisions }\end{array}$ & $\begin{array}{l}\text { (i) Limited or no access to local } \\
\text { politician and tribal leaders } \\
\text { (ii) Their voice is rarely heard in the } \\
\text { public spheres }\end{array}$ \\
\hline Social & $\begin{array}{l}\text { (i) Have strong linkages with all actors } \\
\text { (ii) People never wait their invitations to } \\
\text { help } \\
\text { (iii) Have extended social networks } \\
\text { within and outside the community } \\
\text { (have larger network size) } \\
\text { (iv) Most of their network members are } \\
\text { rich and wealthy HHs }\end{array}$ & $\begin{array}{l}\text { (i) They actively engage in societal } \\
\text { affairs, reciprocate, and get assistance in } \\
\text { return } \\
\text { (ii) Most of their networks are within } \\
\text { their community; however they have } \\
\text { some networks from elsewhere as well } \\
\text { (iii) Most of their network members are } \\
\text { poor HHs }\end{array}$ & $\begin{array}{l}\text { (i) They have very limited network; } \\
\text { people around their networks are often } \\
\text { the poorest } \\
\text { (ii) Their networks are only within their } \\
\text { villages } \\
\text { (iii) They are fatigued of requesting help } \\
\text { from others; they do not do it much }\end{array}$ \\
\hline Human & $\begin{array}{l}\text { (i) Better clothing } \\
\text { (ii) They can afford better health care } \\
\text { (iii) Most of them send their children to } \\
\text { school } \\
\text { (iv) Very good labor condition }\end{array}$ & $\begin{array}{l}\text { (i) They send their kids to } \\
\text { school-however, they drop out at high } \\
\text { school } \\
\text { (ii) Moderate labor condition }\end{array}$ & $\begin{array}{l}\text { (i) Their kids are malnourished } \\
\text { (ii) They educate their kids only up to } \\
\text { elementary level } \\
\text { (iii) Poor labor condition }\end{array}$ \\
\hline Financial & $\begin{array}{l}\text { (i) Mostly have tangible assets and saved } \\
\text { money in the house and banks }\end{array}$ & $\begin{array}{l}\text { (i) Their saving is in their cattle not in } \\
\text { cash }\end{array}$ & (i) No saving at all \\
\hline
\end{tabular}

Participants have first identified major livelihood assets. Accordingly, participants have categorized the wealth level of households into three major categories ("Tujara" for the "wealthy," "Woya" for the "ordinary" or "middle class," and "Miskina" for the "poor"). Community members defined and operationalized each wealth category against possessions of various household assets.

The household wealth categorization (into three major categories) is the same as the categorization of the district's office of rural development and agricultural extension. The only difference that exists is that the different wealth categories in the case of the office were not operationalized based on household's access to and control over the different livelihood resources. The quantitative estimation of the office shows that $12 \%$ of the households are categorized under the wealthy category, while $53 \%$ and $35 \%$ of the households are categorized under middle income and very poor categories.

In general, the table on the community wealth category shows that the first category (wealthy category) seems to have better access to social capital resources than the second and third category. Similarly, the second wealth category has better social capital compared to the third category. However, this does not tell us the implication at household level. It does not also give us any information regarding one's access to and ability to mobilize and utilize different livelihood resources by the virtue of such connections. In order to determine whether one's access to resources from networks to cope with shocks is determined by possession of different livelihood capitals or position in the wealth ladder, we have conducted an in-depth ethnographic interview with the 25 households sampled for the ethnographic interview across the three major wealth categories ( 8 from the wealthy category, 8 from middle class, and 9 from the third category). Households were asked whether access to any of the livelihood resources (operationalized in the community wealth categorization) determines their access to social capital resources and vice versa. Out of the 25 households interviewed, 23 of them have replied affirmatively. These respondents reported that one's access to social capital and other livelihood resources accrued through networks increases with one's access to financial, physical, human, and political capital. Fatuma (a hypothetical name) said the following:

People want to first make sure that you have something to repay their favors with. They want to make sure that you are good for it. They do not want to risk it all. Even your own kin walks 
away from you just because your husband is not around anymore. While my husband was alive, we actually had a lot of people coming to us. Whatever we ask (credit and labor support), we mostly get it right away because they knew that he is good for it. Now, after the death of my husband, when I go to them for help or credit, most of them think many times. Because they know that I cannot give them in time when they need it the most like my husband did.

Another male respondent, named, Mummed, said the following:

\begin{abstract}
If you are poor, no one will be at your doorstep except for the poorest people like you who cannot help you much. If you are poor, no one responds to your call for "Guza" (labor support). If you are poor, you have to sell your crops pre-maturely or rent out your land at a very cheap price. If you are poor, even your own dog will disown you and goes to the rich.
\end{abstract}

Though it is too early to make this assertion, our finding suggests that households better located in the wealth ladder seem to have better social capital and ability to secure support compared to other households living within the same village. This assertion has been further triangulated by several individual interviews and focus group discussions in different villages. For instance, in most of the cases households possessing better human (such as educational background) and physical or natural capital (manpower, land, cattle, etc.) are more likely to have better access to and capacity to mobilize social capital and other forms of capital during the event of shocks. In the case of most of the personalized networks, access to the resources of social capital and the ability to mobilize other forms of assistance or support by the virtue of social capital seem to be conditional upon a household having access to financial capital and other household assets to make the necessary contributions in return. To put it another way, interpersonal or household differences, especially in human, financial, and political and natural capitals, are likely to generate unequal access to the resources of social capital. In the case study community, this is often faced by households located in the third wealth category (Table 1). This finding has been echoed by other empirical researches $[64,65]$. This may also suggest that the condition of being resources-poor may lead to exclusion from exchange networks and from accessing social capital resources. The narrative from the Babille case study could also imply that different categories of households that are placed differently in the wealth ladder can be exposed differently to the same type of shocks and face different constraints and opportunities in the process mobilizing resources to cope with them. This finding agrees with and can be partly explained by Bourdieu's [30] notion of "social field" and Giddens' [66] notion of "human agency": ability to mobilize and utilize resources in the face of adversities. Some actors have more agency and others have less power to influence ways in which events unfold [67]. Thus, depending on their

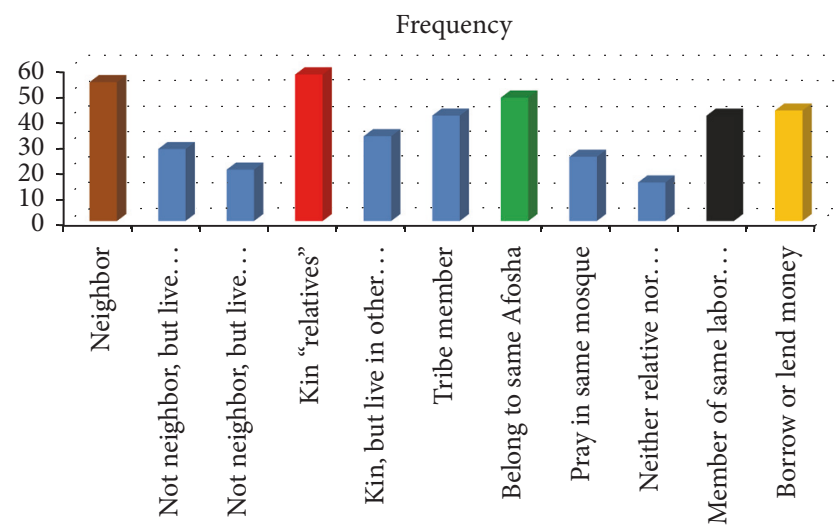

FIGURE 4: Household social network composition and network relationship.

agency, some individuals are likely to have more power and command over resources than others belonging to the same community. This implies that it may be necessary for formal safety net to target and support those households with very little human agencies.

5.1. Networks, Groups, and Collective Action in the Case Study Community. Having described the broader environments that our respondents live in and the effects of shocks on them, our next step is to consider the role of mutual support practices in tackling them. Figure 4 provides descriptive statistics on the characteristics or network composition of individuals found in household networks that were contacted to mobilize resources to cope with any one of the shocks discussed earlier in Table 3.

Kin and relative based support networks are the most important source of assistance (ranked by 57 individuals). Neighbor networks are the second most important sources of assistance (ranked by 54 individuals) for labor, information, and credit. $48 \%$ of the assistance in time of crisis comes from households who belong to the same Afosha (mutual support groups). Belonging to the same borrowing and lending network also brings most support (ranked by 43 individuals). Another very important source of support relationship is tribal relationship. It constitutes the most important source of support for most households (ranked by 41 individuals) in the case study community.

Qualitative analysis obtained from individual interviews and KII reveals important justification on the key role of tribe and kin networks as an important source of support in the case study communities. Ethnographic evidence from Berkelle suggests that tribe and family origin govern households' settlement and residency in the study sites. Berkelle is composed of six different tribes; each of the six tribes share a common place of residence organized along tribal lines. These tribes form six different villages, each standing as isolated geographical units with very low cross-tribal integrations. According to the local elders, in Babille the social units within each village are biologically related to one another and have the same ancestral origin. Each of them also shares common customs and history. These tribes 
not only dictate the residential arrangements of community members, but also shape the pattern how social support should be organized and mobilized within and across tribes. Thus, the tribe-based residential arrangement is considered by individual and households as important avenue to draw on essential resources to cope with shocks and reduce the vulnerability.

In order to be determine the level of proximity and the type of social capital (as bonding, bridging, and linking) that households in the case study community have (by drawing on our conceptual/theoretical framework, Figure 1), we have analyzed the nature relationship based on the place where support comes from most of the time (as within and outside the village) and the nature of relationship between individuals. By using the same data (Figure 4), we can be able to tell that most of the support comes from within the village between households that are very close to one another. We find that only a very tiny amount of support (only 15 frequency point) comes from networks that are neither kin (tribe members) nor members of the same Afosha (mutual support groups). By drawing on our framework, this implies that most of the network types are bonding social capital (closed and exclusive). Only a very tiny percentage of these connections are bridging ties. This has its own merits and demerits in the process of coping with shocks and building effective recovery potential or resilience capacities against shocks and risks. Individual interviews with several households suggest that the low level of residential integration and the lack of cross-tribal cooperation constrain the coping and adaptation trajectories of households for most idiosyncratic shocks. The narrative from the case study communities may seem to suggest that the lack of bridging ties is especially more devastating when a household needs to mobilize additional resources that are not available within the rich of their own networks of family and tribe. This includes access to marketing information, information on agricultural input prices, sharing of agricultural practices, and weather information. In the early stages strong in-group connections may help households in need of access of immediate social support and personal assistance in times of shocks to deal with stressors [42], such as by providing loans to the one who is in need and help them "to get by." On the contrary, having exclusive bonding social capital (lacking bridging ties) could also mean vulnerability. Someone having exclusive access to this form of social capital can also means that it is less likely to break and escape from the cycle of poverty and vulnerability [46]. The implication is that when this kind of networking becomes exclusive, then the network becomes closed hindering the individual's access to other connections that give him/her access to extra resources outside of his/her boundary.

5.2. Typologies of Indigenous Mutual Support Practices in the Case Study Community. Having analyzed the network characteristics, types of relationship, types of connection people utilize, and the general situation our respondents live, in this topic and the next topics to follow we shall discuss the roles of indigenous mutual support practices (both social networks and groups) in the process of building the resilience of households. Our first task will be to identify the typologies of indigenous mutual support practices available in the case study community and the service they provide. The indigenous practices identified were captured using their local names as used by local language called Afaan Oromo (the second widely spoken language in the country).

Drawing on the developed typology (by Midgley, 2011; Patel, Kaseke, and Midgley, 2012) and this study, indigenous mutual support practices employed by communities members to cope with shocks fall under 5 major umbrella typologies (see Figure 5). This includes kin and family based networks (Gumata and Kalu), mutual support networks (Guza network), mutual aid association (Mandara), religiously motivated obligations (Zakat), and gender based groups (women's Afosha).

\subsubsection{Family and Kin Networks}

Gumata. Gumata exists more in social networks; behavior and reciprocity are not regulated and reinforced by standard norms and rules. As a social network, they work based on ties of friends, kinship, religion, neighborhood, and tribal affiliations.

Linguistically Gumata refers to "a gift." Thus, Gumata is mainly meant for a gift in times of sorrow and happiness. Broadly defined, Gumata is a continuing relationship of exchanges/reciprocity that is at any given time can be unrequited or imbalanced, but it involves mutual expectations that a benefit granted today should be repaid in the future. It is believed that any gift must be returned at some point, even if the exact time period is not known. The arrangement predominantly involves exchange/reciprocities during birth of a child, wedding, bankruptcy, theft, fire, crop-failure, death of draft animals, and so on. In case of one of those incidences, a person sends a sincere invitation for help. Invitation will be sent mainly for very close network members and to those whom she/he has already assisted: kin, friends, neighbors, and so on. Indirectly, this call for help is a sincere reminder of getting reimbursement for his/her past contributions. During the occasion, with the exception of new entrants to the network (whom they can pay what they can afford), the rest of them are expected to pay the equivalent of what they have benefited before. However, people do not insist on receiving strict equivalent of what they have contributed. According to key informants, depending on the context, assistance can be organized and rendered to the household in need in a number of ways: each of these presumably having a positive impact in reducing consumption related shocks and preventing asset depletion. For instance, during death of a draft animal, assistance is organized in various ways. If the ox dies or got injured during a pick plowing season, network members (most commonly close relatives, friends, and tribe members) temporarily lend oxen to the person in need. And this is considered a first-hand response to cope with the problem. The other arrangement (a long-term one) involves buying a draft animal and this is usually done in two ways; if the animal is slaughtered before death, then, network members sell the meat to network and nonnetwork members and buy the household a new one. If this is not the case, meaning if the animal is already dead before 


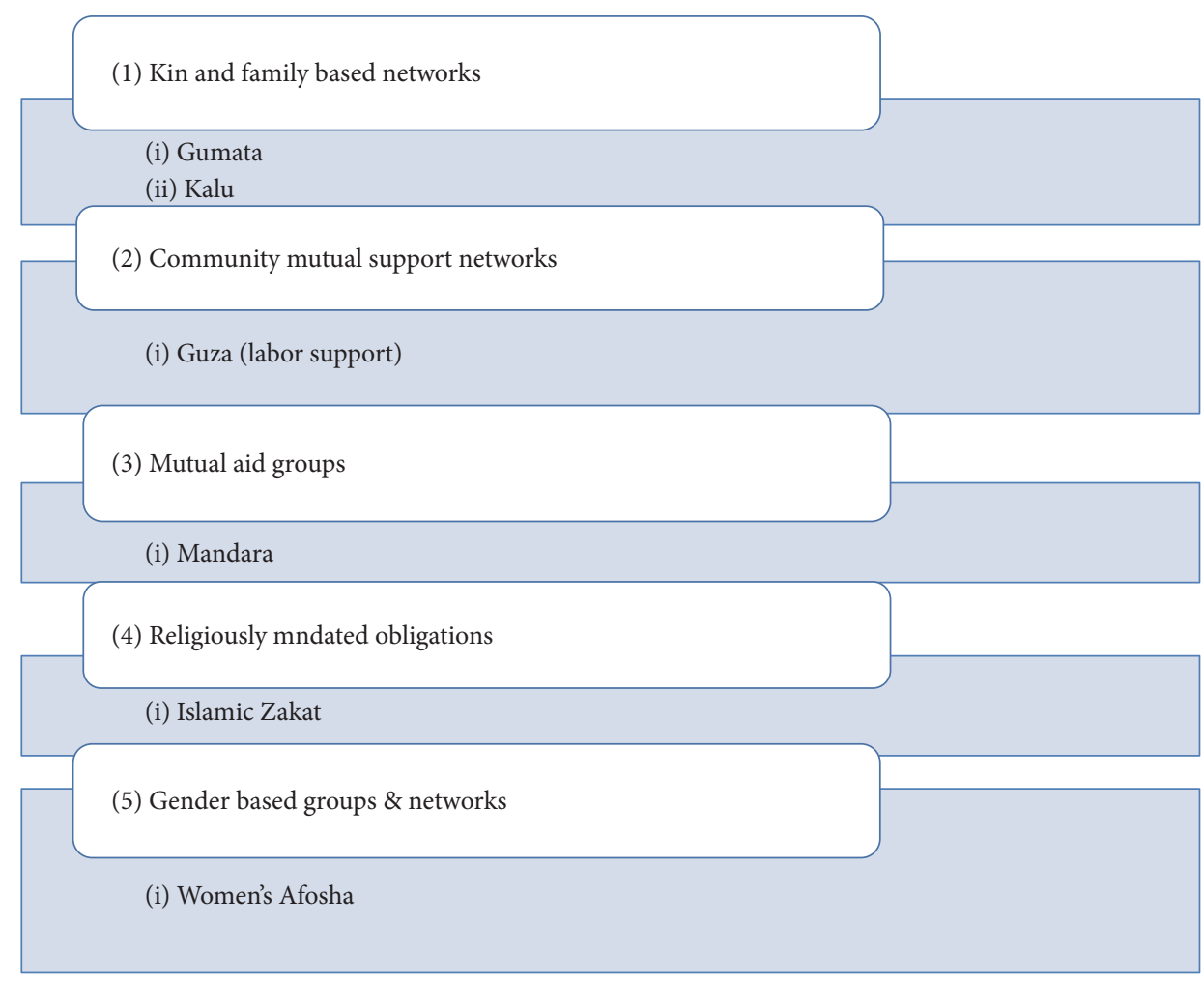

FIGURE 5: Typologies of indigenous mutual support practices.

slaughter, network members will contribute money (part or all of it, depending on the size of the network) to buy the person a new one. On the other hand, during death of network member's close relatives, they have devised a system called "Gumata Awali" or "funeral gift," which is separate from "Mandara." Network members (close friends, tribe members, kin, etc.) contribute both in cash and in kind to console the family of the deceased. Currently, Gumata has been categorized by the local government authorities among harmful traditional practices. Thus, participating in Gumata is a legally punishable act. Government officials justify that Gumata perpetuates poverty and asset depletion as people will be spending the rest of their lives caught up in the vicious cycle of reciprocity and paying contributions. However, many informants and group discussants reject this claim. They instead argue that the decision is politically motivated. An elder key informant says the following:

The decision is purely a political one. It is based on the experience of the previous regime (Derg regime [The Derg is a short name that stands for the regime that ruled Ethiopia from 1974-1987]). To escape from tyranny and oppression of the time, people used to organizing themselves and collect financial and material contributions from community members in the name of Gumata. The significant portion of the contribution directly goes to the backing of armed rebels who fought against the regime. It is this same fear of the past that has driven the government to impose this kind of mindless sanction. Government should understand that the time has changed. People do not have the luxury of sponsoring such armed groups. Our primary goal now is to survive.

Another informant says the following:

I do not know why government is so intolerant for such informal gatherings. It is using many political ploys to systematically smash our solidarity. We are now gradually abandoning an aged old mutual support practice for fear of legal prosecution and possible imprisonment. This decision is ultimately affecting us and our survival ability as a community.

Kalu. Kalu is another mutual support system, which predominantly utilizes social networks. Kalu is born out of the need to assist close relatives, especially newlyweds. Its aim is to support the fresh starters with tangible assets to start their lives. However, Kalu is not meant for everyone in the community; it is particularly meant for the poorest category of households that have limited or no financial means to support their children's wedding expenses. It supports newlyweds and their families by sharing part of the wedding expenses. Dowries (if there is any), furnishing the house of the newlyweds, and financial support after the wedding can be taken care of by this system. In addition to its role in assisting households materially and financially, Kalu has also a solemn duty of protecting youngsters from committing adultery, which 
a rare antisocial-behavior which is highly demonized by community members in the case study community. Close network members within bonding networks (family circles), such as very close relatives, in-laws, and tribe members, have the primary obligation of supporting the newlyweds. Mutual assistance in Kalu is driven by moral obligation, norms of reciprocity, cultural norms, and values. A desire to protect one's family name and tribe from humiliation and disgrace in the eyes of other tribes is also an important driver facilitating such an act of generosity.

\subsubsection{Community Support Networks}

Guza-Labor Sharing Arrangements. Guza is a labor sharing arrangement whereby people reciprocate for labor in agricultural activities (soil preparation, plowing, sowing, weeding, harvesting, threshing, transporting, etc.), house construction, and other labor intensive activities. It functions based on principle of "labor reciprocity on demand." However, in households without active labor force (such as those households whose head has permanent disability, those with old people without caretakers, those with widowed women, etc.), they get free labor support without any conditionality. Whenever a household faces a labor shock or requires additional labor support, it requests the villagers or particularly those who are very close to them (such as family, friends, and tribe members) for labor assistance. Guza predominantly involves the utilization of bonding social capital. And thus in-laws, close friends, kin, and neighbors are the primary providers of assistance. It is the responsibility of the caller to prepare food for the participants. In return, the caller has an obligation to return a reciprocal favor. Failure to attend a call, especially a reciprocal favor, unless for sickness, death, or other commitments (those commonly considered as legitimate excuses), may lead to a serious resentment at first. However, if this behavior is repeatedly happening in patterns, this may lead to the "cutting of ties" with the person and not dealing with him/her whatsoever. And if this behavior is reported to the local elders (those in charge of passing a verdict based on the customary rules of the society), it may lead to sanctioning the person, the highest form of which is "social exclusion." The sanction ranges from not talking to the person up to preventing the children of the defaulter and his/her cattle from mixing up with the rest of the villagers. The sanction may remain effective for quite some time. And this is mostly until the person learns from his mistakes; one of way is by making appeal to the elders.

\subsubsection{Mutual Aid Networks}

Mandara. Linguistically, Mandara refers to "both the village and its dwellers." Mandara is a semiformal/formal arrangement predominantly to insure household's against consumption related shocks resulting from funeral expenses (which are an example of the highest expenses in the locality) during death shocks. Mandara is a village-wide arrangement and thus every household permanently residing in the village (rich or poor) is entitled to benefit from the resources of
Mandara. To qualify for benefit, every household is expected to contribute ETB100 (USD 5) in cash; part of it will be deposited for emergency purposes. The deposit is administered by a trustworthy person. This person should be with better numeracy and literacy. Contribution and participation in Mandara is obligatory. There are different mechanisms in place to maintain the system. Similar to other mutual support practices, fear of social exclusion, anticipation of future benefits, and moral obligation are the drivers for regular participation.

\subsubsection{Religiously Mandated Obligations}

Zakat System. Farmers in Babille, being 100\% followers of Islam as a religion, strictly adhere to and implement most of the Islamic commandments in their personal and communal lives. One of the manifestations of this adherence is the implementation "Zakat." (Zakat is a religious obligation for Muslims to annually contribute a portion of their wealth once it has reached a certain threshold (nisab level). There are two types of Zakat: Zakat al-fitr and Zakat al-mal. The first is a tax on the individual, either male or female, adult or child, at the end of the fasting season (Ramadan) and the second is a tax on wealth. While the former is tied to the performance of Ramadan (a holy month in Islam) fasting, the latter completely depends on someone's possessions (see [54]).) Performing Zakat is a spiritual necessity and an act of piety. Zakat, as a spiritual commandment, is believed by the majority as a mechanism of "cleansing ones wealth" and addressing income inequity; this is by "redistributing resources" from the richer to the poorest category. Usually those households placed within the first and middle class category of the wealth ladder (see Table 4) give away mostly to households in the third wealth or asset holding category (see Table 1). From every $1000 \mathrm{Kg}$ of grains of any kind they produced, they give away $100 \mathrm{Kg}$. However, the system is not institutionalized. As a result, differences in human and social capital among households seem to easily generate unequal access to the resources of Zakat. According to the respondents, those who have better circles and networks get the most of out of it.

Widely being regarded as both a spiritual obligation and a cultural necessity, Zakat is one of those duties rarely neglected by the better off in Babille. There are, however, certain circumstances that are considered legitimate excuses for not being able to fulfill this duty; the advent of covariate shocks (such as weather shocks, conflict, pest, and disease infestations, which affect the whole community) and household specific shocks (that involve sickness of the household head, crop loss, etc.) are among the top-ranking excuses. The fear of God's rage for noncompliance, fear of social exclusion for being stingy, and, on top of all, the likelihood of being in the same situation are mentioned as a factor facilitating generosity and mutual support behavior among households. Besides, since the practice is deeply entrenched in the culture of the society, the cultural norms and values that are used to reinforce cooperation and mutual support behavior in other practices are equally imposed to reinforce and regulate some irregularities in Zakat. 


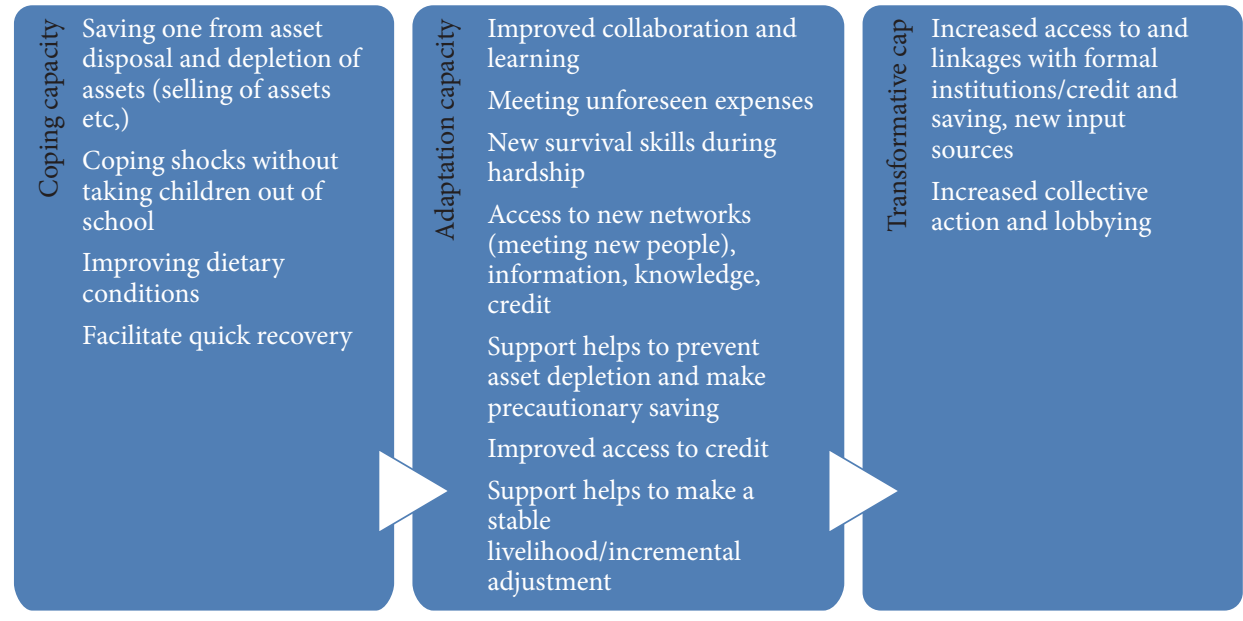

FIGURE 6: Components of a resilient system.

\subsubsection{Gender Based Networks}

Women's Afosha. This is a multipurpose women's indigenous network. Membership is exclusively for married women. Women's Afosha is a collective name given to all types of mutual support and risk-sharing activities managed, supervised, and run by the local women. Over the years they have been evolving adding on new activities and functions depending on the local situation. Table banking or rotating saving groups and milk-collecting groups are (rotating milk saving group) some forms of women's Afosha identified by community members. In addition of such groups based activities, they engage in all sorts of mutual support and social assistance activities including death shocks, sickness shocks, and wedding. While these are not obligatory activities, attendance however is highly recommended. Thus members have a moral and cultural obligation to help. There are different mechanisms in place to maintain the system. Similar to other mutual support practices, fear of social exclusion, anticipation of future benefits, and moral obligation are the drivers for regular participation.

5.3. Roles of Mutual Support Practices in Mitigating Shocks and Building Resilience. Using the theoretical framework that we provided in the beginning of this paper and additional indicators brought up by respondents during interviews and group discussions (see Figure 6), we have generated a list of indicators to evaluate the role of indigenous mutual welfare practices in the process of building the coping, adaptive, and transformative capacities of households in the case study community. Several households have been interviewed pertaining to the role of mutual support groups and networks in building the three resilience capacities. We did the interview at different seasons (across a three-year period). The ethnographic research team has been following some of the mutual support groups and households across the years. Furthermore, we made concurrent and sequential observations, to observe parallel events that are happening every day and capture some aspects of seasonal differences in the way how mutual support networks and groups function across different seasons (including dry seasons of acute food shortage, harvesting seasons, and seasons with high labor demand (to see labor sharing)) and during different events of shocks (covariate and idiosyncratic shocks).

\subsection{Kin and Family Based Networks}

(a) Coping Capacity. Ethnographic data suggests that Gumata does play a coping role against various idiosyncratic shocks that have negative consequences on household consumption. This is by sharing expenses during childbirth (parties) and wedding and financial or material contributions soon after the incidence of theft, fire, crop loss, death of draft animals, death of close family members, and so on. Gumata offers households a quick and reliable first-hand response against vulnerabilities to multiple shocks. And this enables households to make a quick recovery before they already deplete their few productive assets. Several households interviewed stated that they are able to retain their current asset level after one of the above major incidences.

Mummed is a 50-year-old man who lives in one of the villages of Berkelle. He recalls one of the recent fire incidences that he and his family experienced and how they were assisted by his close relatives and tribe members. He said that his family completely lost their house and some of their belongings in a fire accident. "Luckily and thanks to God, I have not lost any family member due to the fire and the fire was also stopped eventually by the support provided by my neighbors," Mummed said. The next morning, my close relatives ( $m y$ in-laws, brothers and sisters, and tribe members) contributed some money, wood and iron sheets. I got my house back in less than a month.

However, this is not for everyone. Ethnographic evidence suggests that households are not at an equal position to 
mobilize and utilize the resources of Gumata to make their way out of shocks. The quantity and type of support that one anticipates accruing from Gumata network during one of these idiosyncratic shocks considerably vary depending on a household's position in exchange networks (and this is a function of one's ability to regularly reciprocate and participate in reciprocity networks, which requires better financial or human capital) and the wealth level of in-laws, tribe members, and other close family members that are in circle. For instance, Bontu is a 45 -year-old woman. She lives in one of the villages of Sheik Hussain. She says the following in relation to the interpersonal differences in access to social capital resources and the amount of support that one could receive in one of the above shocks:

Three years back my family has encountered a major shock. All of a sudden we lost all our cattle due to unidentified disease. The same year, we lost our crop due to bad weather and crop infestations. As you could see my situation, I have not even yet recovered from that problem. My tribe and close relatives are the poorest of all other tribes in this vicinity. Others who have rich in laws and actively participate in reciprocity networks could easily restore wellbeing and get back to normal. Unfortunately we do not have all this. As a result, we were not also able to raise enough resources. The only thing we had to survive was the handouts of neighbors. Some of my young kids had to dropout from school and travel to other places to e feed us and buy us what we lost (at least a pair of oxen) for us to start life again. Currently, they are still in towns working as daily laborers at very young age.

Similar life experiences of respondents also mirror this scenario. Though such networks have very good success record in preventing the worst that could happen to a family, they work well for richer households and families that have good records of reciprocity in exchange networks.

(b) Adaptation Capacity. Analysis of ethnographic evidence suggests that kin and family networks contribute to building household's adaptive capacity to some extent. Such networks reimburse or insure households for their lost income. Recent innovations (such as the introduction of "funeral gifts" in Gumata) demonstrate the presence of learning and incremental innovations in such networks. Nonetheless, Gumata seems to do very little in the area of promoting a sustainable increase in consumption and asset level. It does not also offer much in the area of proactive adjustment to shocks.

(c) Transformative Capacity. Kin and family networks exclusively operate by relying on resources available within the local community. Functioning within a closed knit of family circles with no bridging and linking ties to mobilize resources outside of the family circles, such networks do not seem to contribute to a more radical shift in the livelihood of the poor and their transformative capacities.

\subsection{Community Support Networks (Labor Reciprocities and Support)}

(a) Coping Capacity. Ethnographic data shows that Guza supports households to effectively cope with various labor related idiosyncratic shocks. Interhousehold labor reciprocities between and among households that are in critical shortage of labor and free labor support for those who have no labor capacity seems to facilitate household's recovery process. An informant mentions the following:

\section{During my health challenge, it is by the virtue of this practice that I managed to plow my plot and able to grow and harvest crops which could have otherwise been left fallow or leased-out.}

This and several similar instances suggest that Guza is an important social capital practice in assisting households in their recovery process against various labor related shocks, which, if left uninsured, might be leading to considerable welfare reduction.

(b) Adaptation Capacity. We analyzed the contribution of such community support network (Guza) in helping households and communities in building adaptive capacities, ex ante (before shock) long-term preventive strategy. Though Guza has very little implication towards directly mitigating the impact of predicted shock on a long-term basis, it can indirectly serve as a steppingstone towards the process of creating new assets and capabilities that are essential for adaptation to shocks. By insuring households against labor uncertainties and thus avoiding or minimizing income losses for the household, such networks can facilitate a smooth transition from asset protection to asset building. Ahmedin, a 68-year-old man recalls his experience:

\section{During the harvesting stage, I fell very ill. I remem- ber when the media announced early onset rain. We were told that if the harvest is not collected within two weeks, we may loss it all. Thanks to my neighbors and friends, I received an unconditional labor support in three days. Not only have they harvested the crops but also transported the crop to my home.}

In addition, labor sharing circles help communities exchange and learn new farming techniques and practices from each other. Field evidence (and key informant interviews and observations) suggests that, for years, labor sharing networks have been serving the community as an informal site for on-farm demonstrations through which farmers learn novel practices and jointly innovate in areas that are relevant for an incremental adjustment in their livelihood.

(c) Transformative Capacity. With very limited bridging ties with other community groups and with almost no linking ties to leveraging resources from formal institutions, it seems very unlikely for Guza to build the transformative capacities of individual, household, and communities. 


\subsection{Mutual Support Groups}

(a) Coping Capacity. Mutual support group (Mandara) provides a number of social, economic, and cultural functions, which altogether help reduce household and community's vulnerability against idiosyncratic shocks. This is by sharing funeral expenses, which is one of the highest expenses in the locality. Since they involve every household in the community, they are more inclusive than any of mutual support practices. Besides, by serving as a bridge between several bonding ties available within the community, Mandara helps to mobilize more resources than any of the social capital practices found in the locality. Individual interviews with several households demonstrate that Mandara helps in smoothing households consumption level, thus facilitating their recovery. Hindo is 37-year-old woman who lives in one of the villages of Berkelle with her 5 children and husband. She says the following in relation to this important role of this group:

\section{If you ask me what important resource or saving do you have in a bank for difficult times, I will definitely tell you I have Mandara. I have been assisted several times by Mandara. The local peo- ple are my assets. Mandara cannot exist without the goodhearted people of the locality. We all know the value of one another in this circle. As one cannot clap with one hand, I am no one without this circle. You cannot burry the deceased on your own. Besides, the expenses are unbearable. The burial ceremonies, slaughters, etc. are unbearable. You can easily loss the little you have and starve the next morning. Mandara saves us from all these expenses.}

Burial expenses and farewell ceremony for the departed (which involves cooking food for the whole community, cattle sacrifice for the deceased, tea and coffee, etc.) that are almost unbearable for the individual household can be fully met by Mandara. The family of the deceased will also be left with a modest amount of resources, such as food, money, and drink that can help the household improve its consumption level. However, on top of the material benefits burial associations could offer to bereaving households to cope with shocks, they also provide psychological and sentimental functions. Yet this is one of the least studied and documented roles. Field evidence shows that Mandara contributes to smoothing consumption related shocks that are caused by mental health issues/depression after the incidence of death shocks (especially during death of household head and spouses). Indepth interviews (including with those who have recently lost their spouses and close family members) indicate that mental health issues, most notably depression resulting from death of the household head or other spouses, are major problems inhibiting household's recovery capacities from other shocks that lead to income and consumption reductions. Some households take too long to recover from the sorrow and return to their normal livelihood activities. And this affects the whole family and reduces their income and consumption level. These networks help improve household recovery capacity and promote resilience by shortening the time span between recovering from the shocks and returning to the normal livelihood activities. This is by offering frequent company and consolations to the family of the deceased. Along with the material support provided, the sentimental support facilitates one's ability to return to the normal livelihood activity to support his/her family. We travelled to a cemetery to attend a funeral. Later, we went to the house (a tent prepared for this purpose) to see how the ritual goes and how the villagers help to ease the pain. We sat with the local elders. None of the participants utter a word about the deceased anymore. They talk about current affairs (local politics), religion, and other issues that are not related to death. They believe that this will make the bereaving forget the pains. One of the local elder says the following to us. He started by mentioning the beauty of death when it is done in a community:

You cannot cry alone. I know there is no glory and beauty in crying. But I can assure you that when even crying is done with other people, there is dignity and glory in it. That is why we sometimes say that death in the right place/with company is like a wedding. You cannot mourn alone. Among the Babille's, death is a collective responsibility. It is not an individual responsibility. We share the pain, sorrow and agony. This helps the family of the deceased to recover so quickly. When the whole villager comes to the house of the family of the deceased, we do not even talk about death. We do not glorify death. We do not exacerbate the pain of the person who is mourning by reminding him/her about death and their losses. We already talked about the deceased in the graveyard and we made the necessary prayers. Now, we talk of other things that ease up the pain of the family and give them the moral and spiritual strength. This gives people the energy and the ability to recover so quickly.

This analysis is also echoed by several studies conducted in the developed countries context $[68,69]$ that argued that access to bonding, bridging social capital, civic participation, norms of reciprocity, and trust contribute to preventing depression and improving mental health and resilience capacity. A major limitation of Mandara, however, is that it is limited to only insuring death shocks. Health care expense, which is one of the most alarming expenses for households in Babille due to high animal and human diseases prevalence, is not insured by Mandara. In many other contexts consumption shocks resulting from health care expenses are found to be an example of the principal factors trapping households in poverty [10] and delaying their recovery from shocks.

(b) Adaptation Capacity. Based on analysis of current practices, we find that Mandara partially contributes to adaptation. Mutual support groups provide insurance for households against unforeseen expenses arising from death shocks. Furthermore, the bridging between several bonding ties, which is one of the features of such group, allows households 
to meet new people, engage in new networks, and mobilize novel resources and information that may not be accessed through bonding connections. However, Mandara seems to be highly constrained by budgetary issues. It does not provide insurance against consumption shocks arising from health care expenses. Highly confined within the realm of resources available only within the local community and with no linkage with outside agents, Mandara seems to do very little in enabling household's for a proactive adjustment to shocks.

(c) Transformative Capacity. Analysis of current practices of Mandara suggests that it seems to do very little in supporting households in their pursuit to build transformative capacities. However, with Mandara, being a unique semiformal local organization, there is a huge untapped potential in it that can be mobilized to build the transformative capacities of community members. This can be partly manifested by their well-developed governance and administrative structure that is built on values of traditional "Oromo" (Oromo represents the person who belongs to the Oromo ethnicity; it is one of the biggest ethnic groups in Ethiopia; they approximately constitute more than $34.5 \%$ of the Ethiopian population (see https://en.wikipedia.org/wiki/Oromo_people)) democratic system called the "Gada System" (Gada system is a traditional system of governance used by the Oromo; it is developed from indigenous knowledge and knowledge gained by community experiences over generations; the system regulates political, economic, social, and religious activities of the community dealing with issues, such as conflict resolution, reparation, and protecting women's rights; it serves as a mechanism for enforcing moral conduct, building cohesion, and expressing forms of community culture (https://www.unesco.org/culture/ich/en/RL/gada-system-anindigenous-democratic-socio-political-system-of-the-oromo01164)), one of the oldest indigenous democratic systems in the World. Despite its huge potential in linking community members to outside resources and formal institutions, Mandara generally has a strong detest and lack of trust to any external agents, especially to the government. Any formal attempt to expand the horizons of Mandara is always considered divisive and treacherous and hence always received by community members and their leaders with suspicion.

\subsection{Religiously Mandated Obligations}

(a) Coping Capacity. The analysis of ethnographic evidence on the role of Zakat shows that the timely delivery of Zakat for those who need it the most helps to reduce household's vulnerability to idiosyncratic shocks, smoothens household consumption level, and improves health status and labor condition. In addition, Zakat is one of the most important coping strategies used as a buffer stock for delaying or reducing the displacement/migration of the poorest households to urban areas in the case study community. Several evidences also suggest that when Zakat is given to those who need assistance the most it reduces household asset depletion and hence facilitates their recovery trajectory. Several respondents agree on the role of Zakat in helping poor households from losing the little they have. Meftuha is a 55-year-old mother from Sheik Hussain. She says the following on the role of Zakat:

My husband and I have only a quarter of an acre.
The produce we get is only sufficient to cover our
consumption need for only three to four months.
Thanks to those who give us Zakat, for the rest
of the year, we live by the provision from Zakat.
Though what we are getting from Zakat is not
much, it helped us to keep our kids at school,
protected us from losing our little assets, and
getting displaced.

A major limitation of Zakat system in the case study community is that it is not institutionalized. It appears that the targeting and provision of Zakat do not seem to reflect actual need of households; rather personal acquaintances take the precedence. This process redirects the allocation of scarce resource of Zakat away from those with the most need. As a result, those households with a dire need for assistance are often excluded from receiving the benefits of Zakat. A religious leader says the following:

Actually, most of the time the distribution of
Zakat in our villages and elsewhere in Babile does
not necessarily reflect actual need. People give to
whom they know best. Actually, out of modesty,
pride, and fear of some social stigma, there are
number of households out there who do not go
out and sick for help. It will be good if the mosque
and religious people take the initiative and form
a taskforce to mobilize Zakat and distribute for
those with actual need.

However, field evidence shows that, for the lucky recipients, Zakat is effectively assisting them to cope with consumption related idiosyncratic shocks. This is indicative of the potential that Zakat can offer to the poor if it is institutionalized and supported by formal legislation.

(b) Adaptation Capacity. In principle, Zakat is a system of social welfare that aims at not only addressing income inequality, but also improving the adaptive capacity of households, thus promoting their livelihood situation to effectively cope with future shocks and uncertainties. Analysis of ethnographic data suggests that, given the current structure, level of coordination, targeting mechanisms, resources available in the case study community, Zakat seems to do very little in the area of insuring households against uncertainties. Besides, confined within the realm of resources available within the reach of the local community (bonding networks of friends, neighbors, and relatives), Zakat seems to do little in the area of enabling households creating new assets and capabilities. It is, however, very important to note that Zakat, if coordinated and institutionalized very well, can offer much in the area of building proactive adjustment to shocks.

(c) Transformative Capacity. Zakat, by relying exclusively on local assets and capacities, seems to do very little in building the transformative capacities of households. There is, however, a potential in Zakat to transform and empower poor 
households and promote equity and social justice, boosting self-respect, strengthening good governance, and improving social cohesion and social capital. Practical examples from Asian and North and West African countries suggest that when very well coordinated and institutionalized, Zakat can be actually used to support the transformative capacities of individual, household, and communities. This is by linking households to outside resources and formal institutions, such as with those offering both the Zakat money and training on entrepreneurship.

\subsection{Gender Based Networks}

(a) Coping Capacity. Such networks to some extent help improve household consumption arising from high medical, wedding, and funeral expenses. They include the voluntary contribution of members (which is driven by the norms of generalized reciprocity), in supporting households in the aftermath of shocks.

You know a wedding is one of the highest expenses in the locality. There is hardly a household in all the neighborhoods that feels alright in the aftermath of a wedding ceremony. We invest a lot of resources just for a onetime event. Had it not been for the women's groups, we would have been totally bankrupt. For instance, when my daughter got married last year, the Afosha supported her wedding ceremony by bringing part of the food and drinks from whatever little they have. I have also been doing the same for others.

A major limitation of such networks however is that commitment in most of the activities is not institutionalized. It is a voluntary contribution that may or may not come. Besides, the amount of support one anticipates accruing is highly determined by one's ability to regularly reciprocate, which is a function of income.

(b) Adaptation Capacity. As some of the women's groups have some precautionary saving (table money), they (to some extent) help relive households from unforeseen expenses due to one of the above-mentioned shocks. One of the interesting principles they have in preventing asset household depletion (particularly the table banking group) is prioritizing those in dire need of assistance. Field evidence suggests that women's Afosha, the table banking group, gives the first rounds of payouts for those households that are in critical condition compared to other network members. Hayat, 39, is a widow who lives with her 4 children in one of the villages. She recalls a recent incident of a health shock and how she was prioritized by the Afosha (table banking) when she had to take one of her sick children to a hospital to town:

After noticing that my son was critically ill, I had decided to sale the one and only cow I have to cover the medical expenses. Luckily, when Afosha members saw my condition, they deliberated on the matter and eventually decided to give me the first payout from the table banking (even if that was not my turn) to take care of my son. Consequently, I dropped the idea of selling my cow. The cow is like the mother of my children and my only income source. This is how we work in the group.

However, this kind of network seems to contribute very little to an incremental adjustment in income and enabling households creating new assets and capabilities.

(c) Transformative Capacity. We find certain potentials of such groups (milk-collecting groups) in further strengthening the coping and adaptive capacities of households by linking them to outside resources. Though the experience is not widespread across all the villages, we have seen attempts by the government to work with women's milk banking group and transforming them into formal milk cooperatives. This may suggest that there is a potential in the very nature of some of these groups to facilitate the transformative capacities of women.

Drawing on the theoretical/conceptual framework suggested for this research, in general we find that while community mutual support practices are very effective in building coping resilience by smoothing consumption shocks (improving nutritional and dietary conditions and health status of households) that are mostly resulting from idiosyncratic shocks, they seem to do very little in the area of building adaptive and transformative capacities of individual, household, and communities. Further, while mutual support practices have a close-knit and intensive stock of bonding social capital to enable households insure consumption related shocks and "get by," they have however a negligible possession of extensive bridging social capital to help community members craft crosscutting identities within expansive networks of people to facilitate learning and cooperation to build adaptive capacities and almost utilize no linking social capital to help community members leveraging resources from formal institutions outside of their vicinities to build transformative capacities. They are not also as effective in addressing covariate or systemic shocks affecting the whole community. Further, in some of these practices that predominantly utilize social networks, individual and households might not be at an equal position to mobilize and utilize resources to cope with shocks. Sometimes interpersonal differences in access to financial or human capital may generate unequal access to the resources of social capital, inhibiting the process of individual and household's successful recovery from shocks. There is, however, a lot of potentials and strengths within local forms of social capital to improve the coping, adaptive, and transformative capacities of households with shocks and risks. An important feature they all have in common is that they predominantly employ the bonds of trust and the norms of reciprocity, which helps to deepen bonding social capital. This, in turn, by helping generate the initial trust required to build an informal solidarity, may serve as a bedrock for future cooperation and collective action to build strong adaptive and transformative capacities of community members [28]. Another very important strength these arrangements possess in common 
comes from their "proximity effect" and strong connections, making it more reliable to get support during incidences of idiosyncratic shocks. The strong interpersonal ties that exist between households within bonding ties may make this type of social capital (utilizing bonding ties) good for providing social support and personal assistance in times of need [57]. Besides, the strong cultural norms and spiritual values that underpin generosity and mutual support behavior between individual and households in mutual support networks offer an added advantage to make support more reliable and instant. An even more important feature of mutual support practices in the case study community is that mutual support is underpinned by the norms of "generalized reciprocity." This is characterized by a short-term altruism and longterm self-interest. Though generosity is driven by a mutual expectation that a benefit given today must be repaid in the future, the amount of support, however, can be unrequited or imbalanced at any given time. Generalized reciprocity is argued to be the most productive form of reciprocity [28] to build household and community resilience, sustains and maintains relationships, inculcates sympathy, reduces the possibilities of exclusion of the poorest members of households, and creates more social capital.

\section{Conclusions and Recommendation}

6.1. Conclusion. Shock, especially uninsured shock, remains one of the causes of household poverty and vulnerability in the case study communities. Due to the low level of household asset holdings and capabilities and limited human agency to mobilize resources, shock poses an existential threat to the survival of poor households on everyday basis. The disproportionate majorities of these poor households are smallholder farmers who live and work in destitute conditions without adequate protection and access to services, such as formal insurance, market, and agricultural inputs. Thus, when struck by adverse shocks, they are the ones to suffer the most and face subsequent welfare reduction. Nonetheless, in the absence of adequate support from formal insurance mechanisms and social safety nets, over the years rural households have developed collective and individual risk-smoothing and sharing strategies to buffer and be protected against the effects of livelihood shocks and risks, thus building their resilience capacities. Local forms of social capital, particularly indigenous mutual support practices, are the most important sources of the survival against the pernicious effects of shocks and fulfilling many other sociocultural obligations. Based on the preceding discussions one can conclude that indigenous mutual support practices (IMSPs) are a collective name given to all forms of local level social capital comprised of diverse stocks of risksharing and risk-pooling mechanisms that function based on membership in networks of kinship, residence, tribal origin, neighborhood, and mutual acquaintances underpinned by local customs, shared norms, values, inherited habits, generalized reciprocities, and mutual trust with the object of reducing vulnerabilities to shocks and risks.

Our study suggests that mutual support practices are very effective in building coping resilience by smoothing consumption shocks (improving nutritional and dietary conditions and health status of households) that are mostly occurring from idiosyncratic shocks. However, the traditional coping mechanisms often fail when the shock is systemic or covariate, when household level shock lasts longer or is irreversible, and when a household has low level of human or finical capital. Further, they also do very little in the area of building adaptive and transformative capacities of household and communities. This is due to limited access to bridging and linking social capital required to enable households to leverage resources from individual and communities beyond their localities and formal institutions, such as saving and credit associations, insurance companies, and banks. Backing and complementing informal arrangements by external interventions in areas where they lack the capacity to insure, particularly in building adaptive and transformative capacities, can be vital. It is very important to always note that it is a balanced combination of the three forms of social capital and the three forms of resilience capacities that makes a difference tackling poverty and vulnerability of the poor.

We find that power and relational dynamics and agency factors are important variables that determine access to social capital resources and households' ability to effectively cope with shocks and risks. A person's position in exchange networks is a function of one's ability to regularly reciprocate, which, in turn, is function of one's position in the community wealth ladder. Interpersonal or interhousehold differences, especially in human, financial, and political capitals, may easily generate unequal access to the resources of social capital and access to other livelihood resources. The condition of being resources-poor may lead to exclusion from exchange networks and from accessing social capital resources and this is considered to be one of the limitations of social capital. This implies that individuals and households that are placed differently in the wealth ladder can be exposed differently to the same type of shocks and face different constraints and opportunities in the process mobilizing resources to cope with them. This sends a strong signal to social development policy makers and practitioners to consider resource poor households in their intervention.

Massive structural and institutional barriers that hindered the effectiveness and efficiency of local forms of social capital, lack of trust between politicians and local people, chronic poverty, lack of relative peace and security in the vicinities, and poor performance of agriculture and livestock diseases are important factors that affected social capital use in the case study communities. As a result, for smallholder farmers risk appears to be only partially handled with significant welfare consequences. Nonetheless, it is very important to note that informal arrangements have huge untapped potential that can be harnessed for unlocking human potential and improving the resilience of the poor if complemented by conscious interventions in areas where they lack the capacity.

6.2. Recommendations. Based on the finding of the study, we draw major recommendations with general implications for policy, practice, and development research. The recommendations fall under five broad categories: the first general 
recommendation is on the need to build trust and common understanding. Literature on institutional perspective of social capital [46] suggests that the vitality of community networks is the product of political, legal, and institutional environments under which they are operating; communities and their relationship with the state and its public institutions may determine the performance of local groups to build the resilience of the poor. Promoting social capital for resilience requires local groups to possess a huge political capital and participate in and hold a significant stake in politics and policy entrepreneurship [8, 10]. This requires the removal of major institutional, political, historical, and policy shocks that hinder the ability of poor households to access networks and participate in exchange networks. A major issue here is a lack of mutual trust between the state and local groups $[5,70]$. Over the years, there is a declining term of mutual trust between informal groups, communities, and the state that led to a perception that government is always a threat to autonomy, solidarity, and social cohesion. This has arguably been due to governments' reputations of using informal groups as a space for maneuvering local people for political purposes through use of divisive political ploys. Mutual support groups have long been functioning in isolation by maintaining distance from external agencies. Given the importance state-society/mutual support groups' relationship in improving the resilience of local people, it is a high time to reconcile the state-society relationship. Solution could begin with policy makers recognizing mutual support groups as close allies in their campaign to poverty alleviation. They can start by engaging local people and their institution at different levels through different forums of mutual understanding and partnership to win their trust.

The second area of concern is on the need to build local capacities for resilience. Reciprocity works better when there is more to share [65]. Successful recovery to different types of shocks requires the survival of the fabrics of the social security system or informal insurance that must in turn depend on survival of the livestock system, the ability to grow crops, marketing of the produces, and sharing. A local social capital system may contribute better to the pursuit of sustainable community resilience when households possess bundles of other forms of household assets and capabilities among others. In contrast, poverty and poor resource endowments may limit the amount, diversity, and quality of resources that a household anticipates accruing in time of shocks, thus minimizing the chances of successful recovery. This calls for the implementation of livelihood improvement programs that can help to improve both the vitality of the fabrics of the social security system and household asset level. The purpose of such programs in this regard may be threefold: first, by adding to the resource pool where community draws essential resources to cope with shocks, asset building programs may help to build local assets and capabilities and improve the vitality of community social capital. Second, by enabling the poorest households to build households assets, such programs may promote household's position in exchange networks and prevent their exclusion from reciprocity networks. Third, by providing services that cannot be provided by mutual support groups, this may help to complement existing arrangements. The cumulative effect of all these, in turn, may enable household and communities to make significant transition from short-term survival strategies to more productive long-term investments, thus building strong resilience capacities.

Building local capacity for resilience entails building the capability and assets of individuals and households. This can be done in two ways: livelihood protection and livelihood promotion programs. Protection involves designing and implementing tailor-made social protection policies in the form of both social assistance and social insurance programs. This must be aligned with preexisting mutual support arrangements. This can be performed through formal social safety nets programs that are designed to directly transfer resources to eligible vulnerable groups or households. Some of these protection mechanisms may include provision of health insurance, crop-insurance, and livestock insurance that are not adequately provided by the informal system at the moment. In line with this, it is also very important to design and pursue livelihood promotion programs, such as household asset building programs to enable the most vulnerable groups of households to self-insure and enhance their position in reciprocity networks. These programs however should mainly target the poorest categories of households that have limited access to the local social capital system.

The third major area of recommendation is on the need to work on conflict resolution and cross-tribal integration. Conflict alters the quality of associational and personal lives of households and their ability to mobilize resources to managing shocks. It is because conflict inhibits the development of mutual trust among social groups. The absence of mutual trust, in turn, may reduce the potential gains that a household anticipates accruing from social capital [71] and consequently their resilience capacities. This is because trust is a mechanism that liberates resources [72], lubricates cooperation and engenders reciprocal trust [28], and reduces the cost of beneficial social exchange [31]. Our study shows that tribal and cross-territorial conflicts are the underlying causes that contribute to poor resilience capacities. Fragile state of peace alters the capacity of households and communities to organize and pull themselves together in pursuit of mutually beneficial collective action. By diminishing possibilities for a cross-tribal and residential integration, conflict inhibits the development of mutual trust between individual and households and the formation of dense bonding and bridging social capital. This in turn is likely to reduce the ability of individual and households to access diverse and noble resources to improve their coping and adaptation trajectories. It is, thus, very important to find ways by which to transcend social cleavages and build social cohesion, mutual trust, and solidarity. One way to attain this could be by designing and implementing a more socially inclusive participatory development project that brings together and cuts across several ethnic divides and enables the crafting a crosscutting identities within which bonding can occur. This can be facilitated by the use of different participatory techniques that can facilitate consensus building across different groups [46]. It is also very important to build the capacity of informal groups in the area of conflict resolution. This may include 
integrating informal groups and community leaders with government judiciaries. This may help to prevent escalation of conflict and its management prematurely. Besides, it may also help to improve mutual trust between government and local people.

The fourth area of recommendation is on the need for investment in research and development to promote innovation in the informal sector. Literature now suggests that social networks have a potential to facilitate innovations to bridge the seemingly insurmountable chasms of complex problems to create change across scales, thereby increasing resilience [73]. This is on the presumption that social networks can offer potential conduits for the quick mobilization and transfer of beneficial information and knowledge and therefore can play a key role in the dissemination of social innovations across expansive networks of people, thus enhancing the overall resilience of human and ecological systems. Within this backdrop we argue that the process of building strong and sustainable resilience requires informal institutions to be a hub that promote entrepreneurial behavior, increased collaboration, learning, and innovation. The erroneous assumption and the long held view by policy makers and scholars alike that this sector does not innovate contributed to the long neglect of this sector in development and its potential to be used as a theoretical construct and policy instrument in promoting innovation for resilience. Over the years informal arrangements have been serving the community as a space for learning, collaboration, and innovation (e.g., [8, 10]). For instance, ethnographic evidence from our context has shown that some of these arrangements have gone through subsequent incremental innovations to address the ever growing livelihood shocks of the community. Some of these have evolved to include partial insurance for cattle and sickness shocks. Thus, to enhance the capacity of informal institution to better contribute to building sustainable resilience, it is very important to make a clear account and inventory of these areas of innovation and promote further research in areas they lack the capacity. For instance, one of the problems limiting the far reaching impact of informal arrangements is their limited or no capacity to enable local people to cope with covariate shocks. Research in this area can start by identifying potentials within these arrangements. Consequently, they can think of strategies on how to assist local groups innovate mechanisms for forging better bridging and linking social capital to enable them to build strong adaptive and transformative capacities and hence cope with covariate shocks. This can be further augmented by designing innovation policies that promote research and development in the informal sector.

Finally, it is very critical to undertake exhaustive inventory and assessment of the full stocks of locally based social capital practices prior to any development intervention. Several studies agree on the need to back informal mutual support arrangements for an improved performance [18, 20, $74,75]$. This requires a careful inventory and examination of existing local assets and capabilities and undertakes socioinstitutional analysis. Identifying the type of social capital that exists prior to an intervention helps to identify potential areas of intervention and decide on how government intervention can best complement and build on existing capabilities without doing harm on existing arrangements [10, 28]. It also helps to understand how the proposed intervention will affect the power relations of the different stakeholders and social groups who will be involved and affected by the project.

To retreat, we argue that social capital is one of the most powerful and potential resources that supports the poor in their pursuit for managing risk and vulnerability and building their resilience capacity. This has been demonstrated by their real and perceived potentials in addressing vulnerabilities. Despite this, social capital remains to be one of the most underutilized resources in policy and practice. In a country like Ethiopia where millions rely on mutual support practices to cuff up the necessary resources to manage risk and vulnerability and fulfill many other sociocultural needs, turning a blind eye and not taking it seriously in the design and implementation of intervention policies and practices are lamentable. What we need to understand is that the role of such mutual support practices transcends beyond meeting economic ends of the poor; they are also the space by which society maintains its relationship, regulates its actions and resolves conflict, and redistributes power and wealth and ensures social justice. Therefore, government and other outside agents need to find a way to genuinely complement these practices and work towards the creation and development of community social capital. We argue that the inherent potentials embedded within the mutual support arrangements will only be tapped and become a tool to promote positive development outcome, only if policy makers and development practitioners acknowledge their role and mainstream them in the country's development strategy and complement them by genuine interventions for a more inclusive development.

\section{Disclosure}

This paper has been presented on African Unity and Renaissance Conference and Africa Day Expo held in Pretoria, South Africa, May 21-25, 2017. Please see pages 58-59 in the link below: http://www.hsrc.ac.za/uploads/pageContent/8184/AUR\%20Book\%20of\%20Abstract_fa.pdf.

\section{Conflicts of Interest}

The authors declare that there are no conflicts of interest regarding the publication of this paper

\section{Acknowledgments}

The authors are grateful to Associate Professor Conny Almekinders for her immense contribution at the incubation phase of the work.

\section{References}

[1] FAO, The State of Food Insecurity in the World 2015, Food and Agriculture Organization of the United Nations, Rome, Italy, 2015. 
[2] World Bank, Taking on Inequality: Prosperity and Shared Prosperity 2016, World Bank, Washington, DC, USA, 2016.

[3] D. Clarke and S. Dercon, "Insurance, credit and safety nets for the poor in a world of Risk. Economic and Social affairs," Working Paper 81, DESA, 2009.

[4] S. Dercon, J. Hoddinott, and T. Woldehanna, "Shocks and consumption in 15 Ethiopian villages, 1999-2004," Journal of African Economies, vol. 14, no. 4, pp. 559-585, 2005.

[5] MoA (Ethiopian Ministry of Agriculture), "Ethiopia's agricultural sector policy and investement framework: ten years road map (2010-2020)," Draft Final Report, MoA, Addis Abeba, Ethiopia, 2010.

[6] A. Alemayehu and W. Bewket, "Smallholder farmer's coping and adaptation strategies to climate change and variability in the central highland of Ethiopia," The International Journal of Justice and Sustainability, vol. 22, no. 7, pp. 825-839, 2017.

[7] G. Rapsomanikis, The Economic Lives of Smallholder Farmers: An Analysis Based on Household Data from Nine Countries, Food and Agricultural Organization (FAO), Rome, Italy, 2015.

[8] A. Dejene, "The Iddir: an informal insurance arrangement in Ethiopia," Journal of Saving and Development, vol. 34, no. 1, pp. 53-72, 2010.

[9] G. Berhane, J. Hoddinott, N. Kumar et al., Evaluation of Ethiopia's Food Security Programme: Documenting Progress in the Implementation of the Productive Safety Net Program and the Household Asset Building Programme, International Food Policy Research Institute and Institute of Development Studies, Washington, DC, USA, 2017.

[10] Q. Bernier and R. Meinzen-Dick, Networks for Resilience: The Role of Social Capital, International Food Policy Institute, 2014.

[11] S. Dercon, J. De Weerdt, T. Bold, and A. Pankhurst, "Groupbased funeral insurance in Ethiopia and Tanzania," World Development, vol. 34, no. 4, pp. 685-703, 2006.

[12] R. Bhattamishra and C. Barrett, "Community-based risk management arrangements: a review," World Development, vol. 38, no. 7, pp. 923-932, 2010.

[13] S. K. Mengesha, J. C. A. Meshelemiah, and C. Kasaw, "Assetbased community development practice in Awramba, Northwest Ethiopia," Community Development, vol. 46, no. 2, pp. 164179, 2015.

[14] Y. Nakagawa and R. Shaw, "Social capital: a missing link to disaster recovery," International Journal of Mass Emergencies and Disasters, vol. 22, no. 1, pp. 5-34, 2004.

[15] R. Nigatu, "Small holder farmers coping strategies to household food insecurity and hunger in Southern Ethiopia," Ethiopian Journal of Environmental Studies and Management, vol. 4, no. 1, pp. 39-48, 2011.

[16] I. Petrikova and D. Chadha, "The role of social capital in risksharing: lessons from Andhra Pradesh," Journal of South Asian Development, vol. 8, no. 3, pp. 359-383, 2013.

[17] B. Caeyers and S. Dercon, "Political connections and social networks in targeted transfer programs: Evidence from rural Ethiopia," Economic Development and Cultural Change, vol. 60, no. 4, pp. 639-675, 2012.

[18] D. P. Aldrich and M. A. Meyer, "Social capital and community resilience," American Behavioral Scientist, vol. 59, no. 2, pp. 254269, 2014.

[19] S. Devereux and M. Getahun, Informal and Formal Social Protection Systems in Sub-Saharan Africa, Fountain Publishers, Kampala, Uganda, 2013.
[20] L. Mazur, "Cultivating resilience in a dangerous world," in The State of the World 2013: Is Sustainability, L. Starke, E. Assadourian, T. Prugh, and Worldwatch Institute, Eds., pp. 353363, Island Press, Washington, DC, USA, 2013.

[21] P. Albarran and O. P. Attanasio, "Do public transfers crowd out private transfers? Evidence from a randomized experiment in Mexico," in Insurance Against Poverty, S. Dercon, Ed., Oxford University Press, 2004.

[22] S. Dercon and P. Krishnan, "Food aid and informal insurance," CSAE Working Paper Series 2003-01, Centre for the Study of African Economies, Unversity of Oxford, 2003.

[23] B. Obrist, C. Pfeiffer, and R. Henley, "Multi-layered social resilience: a new approach in mitigation research," Progress in Development Studies, vol. 10, no. 4, pp. 283-293, 2010.

[24] J. Hoddinott, S. Dercon, and P. Krishnan, "Networks and informal mutual support in 15 Ethiopian villages: a description," in Institutional Economics Perspectives on African Agricultural Development, J. F. Kirsten, A. R. Dorward, C. Poulton, and N. Vink, Eds., pp. 273-286, International Food Policy Research Institute, Washington, DC, USA, 2009.

[25] J. Hoddinott and R. Quisumbing, "Data sources for microeconometric risk and vulnerability assessment," Social Protection Paper 0323, World Bank, Washington, DC, USA, 2003.

[26] H. Alderman and C. Paxson, "Do the poor insure? A synthesis of the literature on risk and consumption in developing countries," in Economics in a Changing World. Proceedings of the Tenth World Congress of the International Economic Association, Moscow, A. B. Atkinson, Ed., vol. 4, 1992.

[27] S. Dercon, "Income risk, coping strategies and safety nets," The World Bank Research Observer, vol. 17, no. 2, pp. 141-166, 2002.

[28] R. D. Putnam, Bowling Alone: The Collapse and Revival of American Community, Simon and Schuster Publishers, New York, NY, USA, 2000.

[29] J. S. Coleman, "Social capital in the creation of human capital," American Journal of Sociology, pp. 95-120, 1998.

[30] P. Bourdieu, "The forms of capital," in Handbook of Theory and Research for the Sociology of Education, J. G. Richardson, Ed., Greenwood Press, Westport, Conn, USA, 1986.

[31] F. Fukuyama, Trust: The Social Virtues and the Creation of Prosperity, Free Press, New York, NY, USA, 1995.

[32] M. Woolcock, Using Social Capital: Getting the Social Relations Right in the Theory and Practice of Economic Development, Princeton University Press, 2000.

[33] J. Midgley, "Understanding mutual aid," in Grassroots Social Security in Asia: Mutual Aid, Micro Insurance, and Social Welfare, J. Midgley and M. Hosaka, Eds., pp. 15-28, Routledge, New York, NY, USA, 2011.

[34] L. Patel, E. Kaseke, and J. Midgley, "Indigenous welfare and community-based social development: lessons from African innovations," Journal of Community Practice, vol. 20, no. 1-2, pp. 12-31, 2012.

[35] E. L. Tompkins and W. N. Adger, "Does adaptive management of natural resources enhance resilience to climate change?" Ecology and Society, vol. 9, no. 2, article 10, 2004.

[36] C. Folke, "Resilience: The emergence of a perspective for socialecological systems analyses," Global Environmental Change, vol. 16, no. 3, pp. 253-267, 2006.

[37] S. Carpenter, B. Walker, J. M. Anderies, and N. Abel, "From metaphor to measurement: resilience of what to what?" Ecosystems, vol. 4, no. 8, pp. 765-781, 2001. 
[38] L. J. Hooli, "Resilience of the poorest: coping strategies and indigenous knowledge of living with the floods in Northern Namibia," Regional Environmental Change, vol. 16, no. 3, pp. 695-707, 2016.

[39] S. Christopherson, J. Michie, and P. Tyler, "Regional resilience: theoretical and empirical perspectives," Cambridge Journal of Regions, Economy and Society, vol. 3, no. 1, pp. 3-10, 2010.

[40] F. Berkes, J. Colding, and C. Folke, Navigating Social-Ecological Systems: Building Resilience for Complexity and Change, Cambridge University Press, Cambridge, UK, 2003.

[41] C. Béné, A. Newsham, M. Davies, M. Ulrichs, and R. GodfreyWood, "Review article: Resilience, poverty and development," Journal of International Development, vol. 26, no. 5, pp. 598-623, 2014.

[42] A. Duit, V. Galaz, K. Eckerberg, and J. Ebbesson, "Governance, complexity, and resilience," Global Environmental Change, vol. 20, no. 3, pp. 363-368, 2010.

[43] A.-M. Schwarz, C. Béné, G. Bennett et al., "Vulnerability and resilience of remote rural communities to shocks and global changes: Empirical analysis from Solomon Islands," Global Environmental Change, vol. 21, no. 3, pp. 1128-1140, 2011.

[44] E. Bohensky, S. Stone-Jovicich, S. Larson, and N. Marshall, "Adaptive capacity in theory and reality: implications for governance in the Great Barrier Reef region," in Adaptive Capacity and Environmental Governance, D. Armitage and R. Plummer, Eds., pp. 23-41, Springer, Heidelberg, Germany, 2010.

[45] M. Keck and P. Sakdapolrak, "What is social resilience? Lessons learned and ways forward," Erdkunde, vol. 67, no. 1, pp. 5-19, 2013.

[46] M. Woolcock and D. Narayan, "Social capital: implications for development theory, research, and policy," The World Bank Research Observer, vol. 15, no. 2, pp. 225-249, 2000.

[47] T. Mouw, "Estimating the causal effect of social capital: A review of recent research," Annual Review of Sociology, vol. 32, pp. 79102,2006

[48] G. Gittell and A. Vidal, Community Organizing: Building Social Capital as a Development Strategy, Sage, Newbury Park, Calif, USA, 1998.

[49] J. M. Heffron, "Beyond community and society: the externalities of social capital building," Policy Sciences, vol. 33, pp. 477-494, 2000.

[50] T. Schuller, "The complementary roles of human and social capital," Canadian Journal of Policy Research, vol. 2, no. 1, 2001.

[51] W. Van Oorschot, W. Arts, and J. Gelissen, "Social capital in Europe: Measurement and social and regional distribution of a multifaceted phenomenon," Acta Sociologica, vol. 49, no. 2, pp. 149-167, 2006.

[52] J. S. Hurlbert, V. A. Haines, and J. J. Beggs, "Core networks and tie activation: What kinds of routine networks allocate resources in nonroutine situations?" American Sociological Review, vol. 65, no. 4, pp. 598-618, 2000.

[53] R. L. Hawkins and K. Maurer, "Bonding, bridging and linking: how social capital operated in New Orleans following Hurricane Katrina," The British Journal of Social Work, vol. 40, no. 6, pp. 1777-1793, 2010.

[54] L. Andriani, "Social capital: a road map of theoretical frameworks and empirical limitations," Working Paper, Birkbeck College, University of London, London, UK, 2013.

[55] L. Brown and J. Fox, The Struggle for Accountability: The World Bank, NGOs, and Grassroots Movements, MIT Press, Cambridge, Mass, USA, 1998.
[56] D. Halpern, Social Capital, Polity Press, Cambridge, UK, 2005.

[57] P. Atkinson and M. Hammersley, Ethnography: Principles in Practice, Taylor and Francis Group, New York, NY, USA, 2007.

[58] J. D. Brewer, Ethnography, Open University Press, Buckingham, $\mathrm{Pa}$, USA, 2000.

[59] S. Dercon, J. Hoddinott, P. Krishnan, and T. Woldehanna, "Collective action and vulnerability: burial societies in rural Ethiopia," GPRG Working Paper Series 076, Global Poverty Research Group, Washington, DC, USA, 2007.

[60] B. B. Obaa and R. E. Mazur, "Social network characteristics and resource access among formerly displaced households in Lira, Uganda," Disasters, vol. 41, no. 3, pp. 468-486, 2017.

[61] W. J. Creswell, Qualitative Inquiry and Research Design: Choosing among Five Traditions, Sage, Thousand Oaks, Calif, USA, 1998.

[62] X. Jingfeng, An Anthropological Emic-Etic Perspective on Open Access Practices, Academic Search Premier, 2013.

[63] N. Long, Development Sociology: Actor Perspective, Routledge, London, UK, 2001.

[64] H. Sseguya, R. E. Mazur, and D. Masinde, "Harnessing community capitals for livelihood enhancement: experiences from a livelihood program in rural Uganda," Community Development, vol. 40, no. 2, pp. 123-138, 2009.

[65] M. Heemskerk, A. Norton, and L. de Dehn, "Does public welfare crowd out informal safety nets? Ethnographic evidence from rural Latin America," World Development, vol. 32, no. 6, pp. 941955, 2004.

[66] A. Giddens, The Constitution of Society: Outline of the Theory of Structuration, Polity Press, Cambridge, UK, 1984.

[67] S. B. Ortner, Anthropology and Social Theory, Duke University Press, 2006.

[68] W. Poortinga, "Community resilience and health: the role of bonding, bridging, and linking aspects of social capital," Health and Peace, vol. 18, pp. 286-295, 2012.

[69] S. Han and H.-S. Lee, "Social capital and depression: Does household context matter?" Asia-Pacific Journal of Public Health, vol. 27, no. 2, pp. NP2008-NP2018, 2015.

[70] A. Pankhurst and H. Damen, "The Iddir in Ethiopia: historical development, social function, and potential role in HIV/AIDS prevention and control," Journal of Northeast African Studies, vol. 7, no. 2, pp. 35-57, 2000.

[71] A. Misselhorn, "Is a focus on social capital useful in considering food security interventions? Insights from KwaZulu-Natal," Development Southern Africa, vol. 26, no. 2, pp. 189-208, 2009.

[72] J. Pretty and H. Ward, "Social capital and the environment," World Development, vol. 29, no. 2, pp. 209-227, 2001.

[73] M. Moore and F. Westley, "Surmountable chasms: networks and social innovation for resilient systems," Ecology and Society, vol. 16, no. 1, article 5, 2011.

[74] J. Kamoto, G. Clarkson, P. Dorward, and D. Shepherd, "Doing more harm than good? Community based natural resource management and the neglect of local institutions in policy development," Land Use Policy, vol. 35, pp. 293-301, 2013.

[75] J. Wolf, W. N. Adger, I. Lorenzoni, V. Abrahamson, and R. Raine, "Social capital, individual responses to heat waves and climate change adaptation: An empirical study of two UK cities," Global Environmental Change, vol. 20, no. 1, pp. 44-52, 2010. 


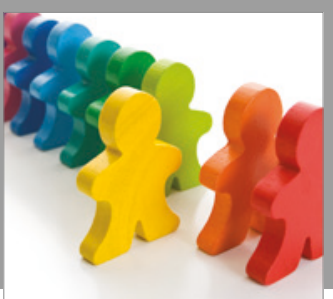

Autism

Research and Treatment
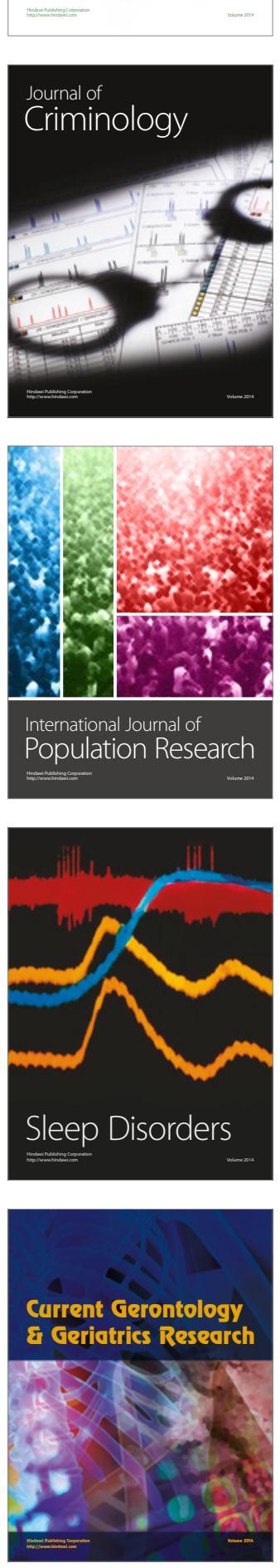

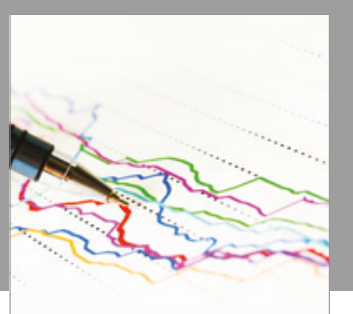

Economics

Research International

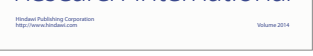

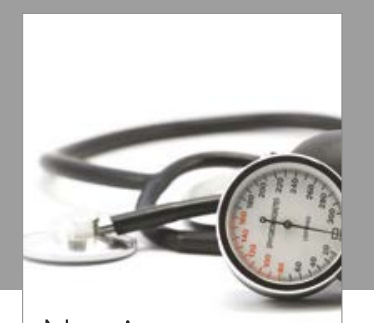

Nursing

Research and Practice

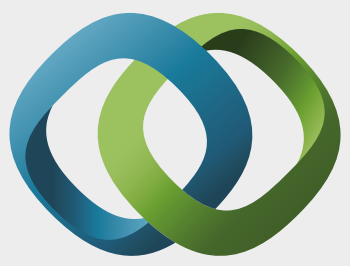

\section{Hindawi}

Submit your manuscripts at

https://www.hindawi.com
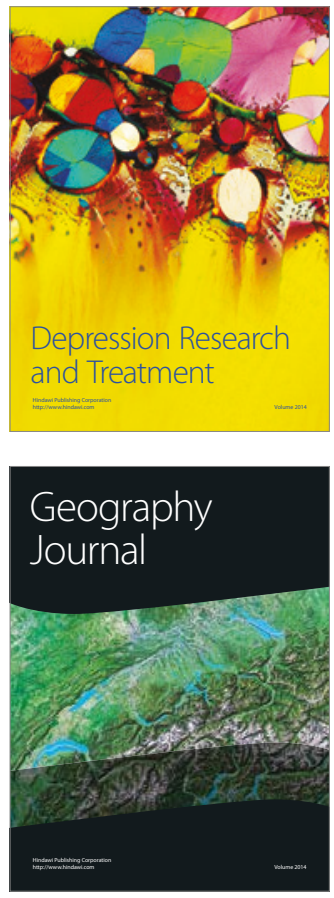
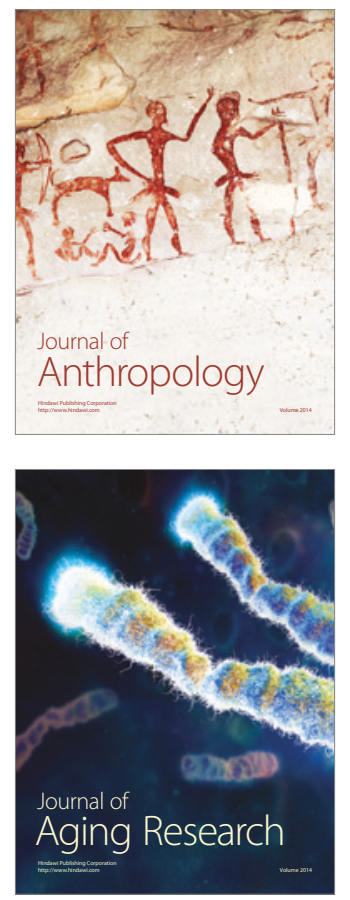
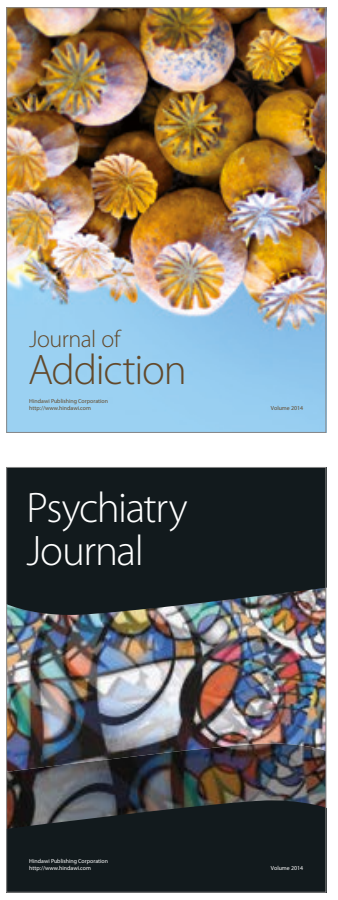

Child Development

Research

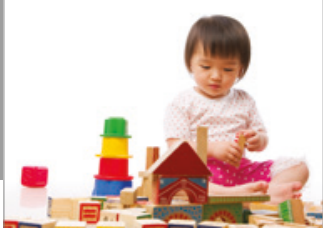

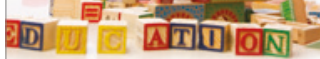
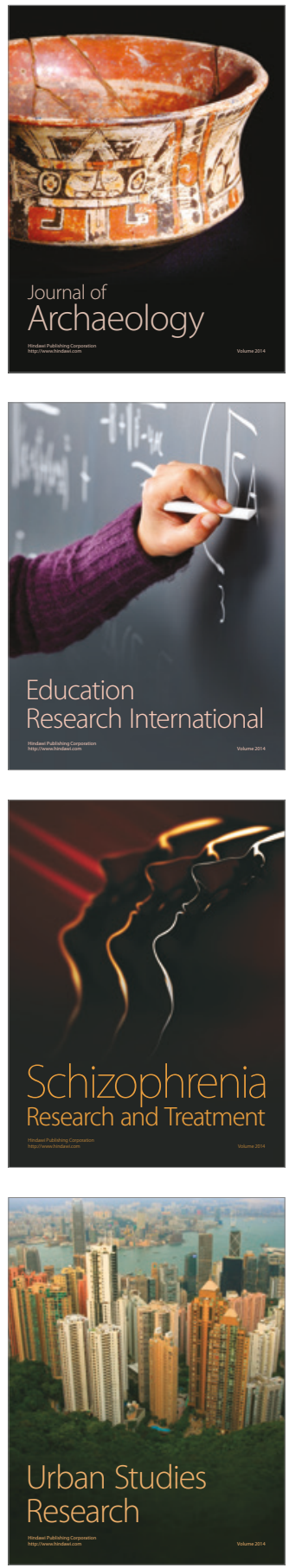